\title{
An analysis of configurations of relationship quality dimensions to explain sources of behavioral outcomes in globalized manufacturing
}

Bodo Steiner

Department of Economics and Management, University of Helsinki, Helsinki, Finland, and

Moritz Brandhoff

JBC Energy GmbH, Vienna, Austria

\begin{abstract}
Purpose - This paper aims to explore the role of configurations of relationship quality dimensions for explaining sources of behavioral outcomes in the globalized manufacturing industry.

Design/methodology/approach - A joint analysis of behavioral and objective performance data from globalized manufacturing links perceptual customer metrics that relate to dimensions of relationship quality (i.e. attitudinal loyalty, perceived customer orientation, customers' perceived innovativeness of the supplier and perceived customer influence on supplier innovation) with behavioral outcomes (i.e. share of wallet (SOW) and customer account profitability). Using data from a global business-to-business (B2B) customer survey together with archival performance data from a multinational mechanical engineering firm, a fuzzy set qualitative comparative analysis (fsQCA) is performed.

Findings - The fSQCA results suggest that perceptual customer metrics related to innovation can be relevant aspects of relationship quality, in line with Anderson and Mittal's (2000) satisfaction-repurchaseprofitability chain framework and its adaptation to SOW. However, the underlying complexities in the different combinations of attributes in the recipe are such that they are not equifinal in leading to higher SOW or higher profitability. This paper finds indications for non-linearities between perceptual measures investigated and profitability of customer accounts, with particular relevance for the role of perceived customer orientation, perceived product innovativeness of the supplier and attitudinal loyalty.

Research limitations/implications - The analysis faces a number of limitations, starting with its reliance on cross-sectional survey data, which does not enable us to account for feedback mechanisms, for example, arising from customer perceptions regarding innovation aspects. The lack of a multidimensional conceptionalization of the perceptual customer constructs may have limited the analysis, considering also recent evidence from retail companies in the furniture sector in Spain, suggesting that the multidimensional conceptualization of relationship value explained satisfaction and loyalty levels to a greater extent than the one-dimensional conceptualization (Ruiz-Martínez et al., 2019).
\end{abstract}

(C) Bodo Steiner and Moritz Brandhoff. Published by Emerald Publishing Limited. This article is published under the Creative Commons Attribution (CC BY 4.0) licence. Anyone may reproduce, distribute, translate and create derivative works of this article (for both commercial and noncommercial purposes), subject to full attribution to the original publication and authors. The full terms of this licence may be seen at http://creativecommons.org/licences/by/4.0/legalcode

The authors gratefully acknowledge feedback that they received from the presentation of an earlier version of this paper at the 78th Annual Meeting of the Academy of Management, August 10 14, 2018, Chicago, Illinois, USA.

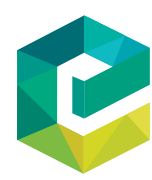

Received 14 October 2018 Revised 22 November 2019 21 May 2020 
EJM

55,13

Practical implications - In terms of managerial implication, the results suggest that customers perceive limited value in participating in the focal firm's innovation value chain funnel, hence customer loyalty cannot be bought using simple incentive strategies. The results with regard to customer account profitability suggest that $\mathrm{B} 2 \mathrm{~B}$ customers investigated here may distinguish when interacting with their globalized supplier in the innovation funnel: they may see a positive customer value when the innovation is a product, and thus, relation-specific, whereas they may see limited customer value when innovation is considered in more generic terms (customers' perceived influence on supplier innovation in general).

Originality/value - This paper starts from the premise that perceptual customer metrics can matter for supplier performance, as the customer relationship and customer value management research has shown. However, there is limited empirical evidence from globalized manufacturing sectors incorporating perceptual constructs in behavioral outcomes, and limited evidence assessing customerperceived value in such sectors through alternate approaches to main-effects focused analyzes. We employ qualitative comparative analysis using fuzzy sets (Russo et al., 2019) to address these gaps, focusing on two key behavioral outcomes, namely, customer account profitability and SOW.

Keywords Innovation, Customer catisfaction, Manufacturing industries, Global business, Share of wallet, Mechanical engineering, Loyalty, fsQCA, B2B customer value, Perceptual customer constructs

Paper type Research paper

\section{Introduction}

Perceptual customer constructs have been analyzed extensively in the customer relationship and customer-value management literature with a focus on customer satisfaction, retention and profitability metrics (Verhoef et al., 2007; Flint et al., 2011; Keränen and Jalkala, 2013; Lemon and Verhoef, 2016; Kumar and Pansari, 2016a; Kumar and Reinartz, 2016b; Bindroo et al., 2020). To influence such metrics, companies have aimed at influencing both customer perceptions and engagement (Dwyer et al., 1987; Narver and Slater, 1990; Gligor et al., 2019). Notably, to influence customer-perceived value, companies have used different ways to integrate customer feedback mechanisms (Lapierre, 2000; Ulaga and Chacour, 2001). A growing literature has thus, investigated perceptual customer metrics and their impact on financial and non-financial performance indicators (Gruca and Rego, 2005; Gupta and Zeithaml, 2006; Sorescu and Sorescu, 2016). Homburg et al. (2013) have furthermore analyzed organizational customer outcomes, distinguishing a supplier's actual engagement in business practices (corporate social responsibility) from customers' perceptions of these business practices.

Yet, in spite of extensive work on perceptual customer constructs, and a detailed understanding of the multi-dimensional nature of customer engagement (Brodie et al., 2011, 2013; Kumar and Pansari, 2015; Beckers et al., 2017; Harmeling et al., 2017), we still lack understanding of customer engagement (Lilien, 2016), especially in those applications of customer engagement where perceptual constructs are directly incorporated into behavioral outcomes (Kamakura et al., 2002; Gupta and Zeithaml, 2006; Kumar et al., 2013; Vivek et al., 2019). Furthermore, in these applications, we are missing a deeper understanding of combinations of antecedents, to better explain behavioral outcomes in globalized manufacturing. The objective of our paper is, therefore, twofold. First, to address the research question: what are the possible configurations of relationship quality dimensions for explaining sources of behavioral outcomes in the globalized manufacturing industry? And second, to addresses three research gaps while answering this question. First, we aim to address the gap identified in the literature that more work with behavioral data would be preferable, especially in analyzes of share of wallet (SOW) (Buoye, 2016). Second, we seek to contribute to addressing the gap of analyzes on the role of customer innovation perceptions in global B2B manufacturing markets. And third, we address a methods application gap in the context of perceptual constructs and customer loyalty analyzes applied to 
manufacturing sectors, noting that Russo et al. (2016) call for more research that should consider other possible combinations of antecedents of customer loyalty, while using alternate approaches to main-effects focused multivariate regression analyzes (Gligor et al., 2019).

Our paper contributes toward closing the above gaps in four ways. First, by studying multiple dimensions of relationship quality jointly with behavioral and objective company performance data, while assessing metrics of relationship quality associated with innovation together with key relationship quality metrics unrelated to innovation. More specifically, we explore components of customer relationship quality with regard to behavioral loyalty (SOW) and customer account profitability, accounting for customers' perception of their influence on supplier innovation, and accounting for customers' perceived product innovativeness of the supplier. The fact that our B2B analysis also covers innovation measures from the perspective of the customer puts us apart not only from an extensive literature that has explored the relationship between customer satisfaction and customer loyalty, both attitudinal and behavioral (Fornell et al., 1996, 2016; Szymanski and Henard, 2001; Gupta and Zeithaml, 2006; van Doorn and Verhoef, 2008; Walsh et al., 2008; Naumann et al., 2009; Williams and Naumann, 2011; Dagger and David, 2012; Kumar et al., 2013; Buoye, 2016) but also from customer value management works with a focus on customer behavior toward innovations (Zhang et al., 2016).

Second, we contribute to the above gaps by applying a fuzzy set qualitative comparative analysis (fsQCA), to investigate configurations of relationship quality dimensions to explain sources of behavioral outcomes. This analytical focus allows us to uncover possible complexities underlying the key constructs under investigation, thereby going beyond the study of main effects analyzes of outcome predictors, such as previous regression-based analyzes that have accounted for associations between perceptual customer metrics and performance metrics (Anderson and Mittal, 2000; Keiningham et al., 2003; Kwiatek et al., 2020). Our application of fsQCA, thus also contributes to the body of work on customer loyalty in the B2B context, and on customer engagement research applying fsQCA (Russo et al., 2016; Santos et al., 2018; Gligor et al., 2019).

Third, while adopting Anderson and Mittal's (2000) satisfaction-repurchase-profitability chain framework (SRF) and its adaptation to SOW (Keiningham et al., 2005; Cooil et al., 2007) as a conceptual framework, our paper contributes to the literature on perceptual constructs of customer satisfaction, customer loyalty and absolute perceptual metrics (Buoye, 2016; Kumar et al., 2016b; Mittal et al., 2018), which is dominated by evidence from banking and services sectors, rather than providing evidence from manufacturing markets. Fourth, in light of our customer value metrics used focusing on innovation perceptions, we contribute to relationship value insights from the perspective of the customer (Ulaga and Eggert, 2006), contribute to the literature linking customer value and loyalty (Cretu and Brodie, 2007), and to the literature on collective value-in-use in the context of customer loyalty (Macdonald et al., 2016; Eggert et al., 2019).

Our joint analysis of perceptual constructs with behavioral outcomes is owing to customer responses to a global B2B customer survey $(n=616)$ associated with a multinational supplier from globalized industrial manufacturing, and to associated objective company performance data. The supplier in question is a multinational mechanical engineering firm, headquartered in Europe [1]. The global mechanical engineering sector in which this multinational operates takes a fundamental role to most branches of industry (Steiert, 2008; Gardner, 2016), and also takes a central role in the EU economy with mechanical engineering being one of the largest industrial sectors in terms 
$\mathrm{EJM}$

55,13

of number of enterprises, employment, production and the generation of added value (EC, 2018).

The remainder of the paper reviews relevant literature and develops corresponding propositions (Section 2), followed by a presentation of methods and results (Section 3), conclusions, limitations and opportunities for further research (Section 4).

\section{Literature}

In light of the complexity with respect to possible multiple paths leading to the performance outcome measures we are interested in (SOW and profitability), and before we are applying complexity theory (Spivack and Woodside, 2019) to investigate these outcomes, we first need to delineate the antecedent configurations. We do this by reviewing the relevant literature, linking key dimensions of relationship quality relevant to our globalized manufacturing supplier (i.e. attitudinal loyalty, perceived customer orientation, perceived innovativeness of the supplier and perceived customer influence on supplier innovation) with behavioral outcomes (i.e. customer account profitability and behavioral loyalty). Before we review these metrics of unobservable customer constructs and behavioral outcomes, the question of comparability and transferability of insights from business-to-consumer to B2B research arises. Homburg et al. (2013) emphasize the key fact that individuals make the purchase decisions in both contexts. Yet, the review from Guzmán et al. (2012) on B2B branding and related constructs highlights the fundamentally more complex B2B domain, typically involving more decision-makers, different communication channels and longerterm relationships with customers, with a corresponding potentially greater role for customer loyalty (Bennett, et al., 2005; Rauyruen et al., 2009). Furthermore, Homburg et al. (2013) consider the differences that may arise because of three central characteristics of organizational buying, highlighting the reliability of the supplier as a key factor, as organizational customers typically put greater emphasis on long-term supplier relationships (Mitchell, 1995). B2B work on retailer loyalty confirms this importance of supplier reliability, highlighting the relevance of technical and relational dimensions of a manufacturer's order fulfillment service quality as predictors of retailer loyalty behavior (Davis-Sramek et al., 2009). Overall, the majority of B2B evidence comes from supply-chain and industrial marketing applications (Russo and Confente, 2017b), including a cross-sectional study on purchasing managers in US manufacturing industries (Eggert and Ulaga, 2010), a study on value-based selling (Terho et al., 2017) and evidence from the audiology industry on the relationship between returns management and repeated purchase intent (Russo et al., 2017a).

Previous customer analysis research with a focus on unobservable customer constructs has centered on customer perceptions (e.g. service quality), customer attitudes (e.g. customer satisfaction) and behavioral intentions (e.g. intentions to purchase) (Woodruff, 1997; Gupta and Zeithaml, 2006; Tomczyk et al., 2016). The review provided by Gupta and Zeithaml (2006) divides this literature into three camps, those papers focusing on the link between the impact of unobservable constructs on financial performance, those focusing on the impact of unobservable constructs on observable metrics (e.g. the link between satisfaction and retention), and those papers studying the impact of observable constructs on financial performance. Our paper falls into the first camp of linking unobservable constructs with observable ones, incl. behavioral loyalty (SOW) and a focal firm's profitability of a given customer account. The following sections draw on existing theory, discussing these constructs and relationships conceptually and empirically, paving the way for deriving our propositions as part of an inductive modeling approach [2].

As our discussion of behavioral outcomes and their antecedents with respect to dimensions of relationship quality centers around customer perceptions and customer 
involvement, we take Anderson and Mittal's (2000) model underlying a satisfactionrepurchase-profitability sequence (and its adaptation to SOW, Keiningham et al., 2005; Cooil et al., 2007) as our conceptual underpinnings. Further, we consider customers' perceived degree of involvement in supplier innovation as an intangible asset embedded in customer-supplier relationships, and assume that such relational assets can be converted into customer value (Srivastava et al., 1998). This customer value is understood with respect to an ongoing B2B relationship, and hence, as value-in-use, the latter being of interest because of its embedded understanding that customers can assess the quality of the product usage process, and that this is relevant for customer loyalty (Sirdeshmukh et al., 2002; Grönroos, 2011; Ritter and Walter, 2012; Macdonald et al., 2016). This value-in-use perspective leads us toward a better understanding of the antecedents of the willingness of customers to engage in value creation (Grönroos and Helle, 2010; Cassia et al., 2015; Macdonald et al., 2016; Eggert et al., 2018; Eggert et al., 2019). Furthermore, customer value perceptions are not only important for a general conceptualization of customer-perceived value (Ulaga and Chacour, 2001; Flint et al., 1997) but also for defining relationship value with suppliers (Ulaga and Eggert, 2006), including experienced value in use (Eggert et al., 2019).

To gauge the costs and benefits of greater customer engagement and relationship value from the perspective of the focal company, suitable measurements and analytics are required (Keränen and Jalkala, 2013; Germann et al., 2013; Aksoy, 2013). Suppliers have thus, frequently integrated customers into their knowledge-generating process through perception surveys (Dunphy and Herbig, 1995; Woodruff, 1997), as the derived perceptual customer metrics can provide insights into the extent to which a focal firm's value proposition and capabilities are met (Day and Wensley, 1988; Oliver, 1999; Verona, 1999; Gupta and Zeithaml, 2006; Carlson et al., 2015). As part of supplier-customer relations, customer value perceptions have also proven valuable, as customer value anticipation has been found to be a strong driver of satisfaction and loyalty (Flint et al., 2011).

While we aim to investigate configurations between perceptual customer metrics that relate to diverse dimensions of relationship quality and behavioral outcomes, we are particularly interested in customer innovation perceptions, as these may be particularly relevant to suppliers in globalized manufacturing. When considering the role of customer value perception in the context of a firm's innovativeness, we could expect that the integration of customer value judgment has increasing relevance in more open innovationfocused business models with greater customer interaction (Herstatt and von Hippel, 1992; Chesbrough, 2005, 2006; Ili et al., 2010; Almirall and Casadesus-Masanell, 2010). Such openness may not only drive firm growth in general (Xia and Roper, 2016). An inclusion of customers in innovative processes may derive more customer-centered products (Füller and Matzler, 2007), improve mutual understanding (von Krogh et al., 2000) and lead to greater innovation performance (Prahalad and Ramaswamy, 2004; Desouza et al., 2008; Foss et al., 2011; Kostopoulos et al., 2011; Gemser and Perks, 2015; Kazadi et al., 2016). While the extent of customer involvement in new product development has been found to be a function of the degree of radicalness of innovations (Candi et al., 2016), a number of costs have, however, also been associated with greater market orientation (von Hippel, 1982; O'Cass et al., 2012; Smals and Smits, 2012; Najafi-Tavani et al., 2016). In particular, costs associated with greater customer involvement in innovation may include higher development times (Greer and Lei, 2012) and an increase in coordination costs (Almirall and Casadesus-Masanell, 2010). Furthermore, we could consider the novel introduction of business practices by a supplier as practice innovations, and thus, be interested in buyers' perceptions of such 
$\mathrm{EJM}$

55,13

innovations. Applying structural equation modeling, Homburg et al. (2013) have indeed analyzed customers' perceptions of corporate social responsibility business practices.

In preparing for the development of our propositions, the following sections draw on existing theory and concentrates on two key behavioral outcomes under investigation, behavioral loyalty (SOW) and customer account profitability. Considering our joint focus on behavioral and attitudinal loyalty, Watson et al. (2015) note that the very definition of loyalty lacks consensus (Day, 1969; Dick and Basu, 1994; Melnyk et al., 2009), though the review by Watson et al. (2015) concludes that, from a conceptual standpoint, customer loyalty is a collection of attitudes aligned with a series of purchase behaviors that systematically favor one entity over competing entities (Watson et al., 2015, p. 803). While we relate to both attitudinal and behavioral loyalty in the following analysis, Watson et al. (2015, p. 791) also note that the common research practice of using single-element measures of loyalty (i.e. only attitude or behavior) leads to mixed guidance regarding the effect of loyalty on performance.

\subsection{Attitudinal loyalty, behavioral loyalty and customer account profitability}

Early distinctions of attitudinal and behavioral loyalty have been put forward by Day (1969) and Dick and Basu (1994). Dick and Basu (1994) highlight previous operationalizations of loyalty through indices that include attitude and purchase frequency (Jacoby and Chestnut, 1978), as well as the anchoring of attitudinal loyalty as a relative construct in terms of an association between an object and an evaluation in attitude-behavior relations models (Ajzen and Fishbein, 1980). In summarizing the literature, Kumar and Reinartz (2018, p. 182) suggest that behavioral loyalty encompasses the observed actions that customers have demonstrated toward a particular product or service, whereas attitudinal loyalty includes perceptions and attitudes. Components of definitions of behavioral loyalty in the literature encompass customers' willingness for repurchase (Rauyruen and Miller, 2007), as well as repurchase intention, cross-buying intention and willingness to recommend (Huang et al., 2017), which all point us to expect that long-term supplier relationships matter particularly in the B2B domain (Mitchell, 1995). In contrast, perspectives on attitudinal loyalty include price tolerance and the degree of self-recognized loyalty (Huang et al., 2017), as well as customers' psychological attachments and attitudinal advocacy (Rauyruen and Miller, 2007; Casidy and Wymer, 2016).

Anderson and Mittal's (2000) model of a satisfaction-repurchase-profitability sequence is anchored in attitude-behavior relations models (Fishbein and Ajzen, 1975; Eagly and Chaiken, 1993; Mittal and Kamakura, 2001). Here, the theory of reasoned actions (Ajzen and Fishbein, 1980) implies that attitudes influence behavioral intentions and subsequent behavior. The importance of customer satisfaction for customer retention and facilitating behavior (repurchasing), and the link between repurchase intentions and SOW is empirically well-established in B2B markets (Hennig-Thurau and Klee, 1997; Keiningham et al., 2003; Cooil et al., 2007; Keiningham et al., 2007; Meyer-Waarden, 2007; Voss et al., 2010; Reinartz and Eisenbeiss, 2015). It is further conceptually supported by Mittal and Kamakura's (2001) model underlying a satisfaction-repurchase-profitability sequence, suggesting a non-linear relationship where loyalty investments may be recovered in the longer term. Empirically, there is evidence for a positive and non-linear relationship between customer satisfaction and SOW, from mostly banking and retail sector firms (Gupta and Zeithaml, 2006; Cooil et al., 2007; van Doorn and Verhoef, 2008; Williams et al., 2011; Buoye, 2016), although the evidence is nevertheless inconclusive as to the nature of the non-linear relationship (Reinartz and Kumar, 2000, 2002; Mägi, 2003; Hofmeyr et al., 2008; Reinartz and Eisenbeiss, 2015). Such evidence is further complemented by experimental insights, which suggest that 
customer satisfaction increases customers' willingness to pay, with increasing returns (Homburg et al., 2005).

Anderson and Mittal's (2000) SRF has also received support from studies that put forward a positive association between loyalty and customer profitability (Reichheld, 1996; Reichheld et al., 2000). However, the literature on customer loyalty in relationship marketing also points to a possible weakness, and thus, the complexity of the association between loyalty and profitability (Ganesan, 1994; Dowling and Uncles, 1997; Söderlund and Vilgon, 1999), while highlighting that the length of the relationship is important for explaining the positive loyalty-profitability association (Storbacka et al., 1994). More recent work indicates that this association between loyalty and profitability is further nuanced (Kumar, 2016: "profitable loyalty"), noting that long-term customers can also be unprofitable, and thus, costs of maintaining a customer relationship can be central (Reinartz and Kumar, 2000; Niraj et al., 2001; Reinartz and Kumar, 2002; Kumar and Rajan, 2009), while highlighting that different results on profitability are a function of whether transactional or relational customers are considered (Sharma, 2007). Further, a weak association of attitudinal loyalty in terms of repeat buying with profitability may also arise from switching costs (Burnham et al., 2003; Lam et al., 2004). Notable evidence on the attitudinal loyalty and profitability nexus also relates to the nature of the firm, as evidence from Edvardsson et al. (2000) suggests that for product firms, loyalty can have a negative effect on financial performance, while for service firms the effect can be positive. Furthermore, evidence from the Norwegian fishing industry provides weak support for a non-linear relationship between customer loyalty and higher customer profitability (Helgesen, 2006).

\subsection{Customer's perceived influence on supplier innovation and loyalty}

When a customer perceives scope to influence supplier innovations, we could expect this underlying democratizing of innovation (von Hippel, 2005) to contribute to a customer's increased perceived appropriability of returns to his relationship investment with the supplier (Grant, 1991; Kleinaltenkamp et al., 2015), and to greater attractiveness of the customer to the focal supplier. It is, thus, of interest to note that customer attractiveness to a given supplier has been found to help attaining preferential resource allocation from the supplier (Pulles et al., 2016). Using fsQCA, Wu et al. (2016) also find evidence for the role of such relationship investment with the supplier, in that in line with transaction cost economics, some specific asset investment positively associates with a firm's loyal behavior. Furthermore, the perceived capabilities of suppliers to innovate could also be considered an important part of a supplier's capability profile (Möller and Törrönen, 2003). These considerations suggest not only that customers' perceived influence on supplier innovation is potentially a relevant aspect of supplier collaboration but also that such increased supplier attractiveness could lead a given customer to allocate a greater revenue share to this supplier. More recent work has also shown that customer involvement in a supplier's innovation activities is reflected in customer's perceived value of the supplier-buyer relationship, which can ultimately influence behavioral value outcomes (ArslanagicKalajdzic and Zabkar, 2015). This finding from Arslanagic-Kalajdzic and Zabkar (2015) reinforces our expectation from the Anderson and Mittal (2000) chain framework and its adaptation to SOW (Keiningham et al., 2005; Cooil et al., 2007), namely, that perceived influence on supplier innovation can be positively associated with SOW.

Considering the conceptual underpinnings of Anderson and Mittal (2000), we also note that increased customer attractiveness to a focal supplier could be rationalized with attitudebehavior relations models (Ajzen and Fishbein, 1980; Eagly and Chaiken, 1993), as these models have been found to explain that customers' perceived behavioral control (customer's 
$\mathrm{EJM}$

55,13

perceived influence on supplier innovation, in our case) can contribute to their attitude toward remaining in a supplier-customer relationship (Guo et al., 2009). Linking such attitude to remain in a supplier relationship with SOW, Blut et al. (2016) have shown that switching costs as part of buyer-seller relationships in B2B markets can impact SOW, while Russo et al. (2016) have applied QCA to demonstrate the role of switching costs in an analysis of loyalty drivers in the health-care industry. Burnham et al. (2003) explore a broad set of switching cost facets, to supply evidence from the insurance sector that such switching costs cannot only be of financial nature, but can also include relational and procedural costs, such as learning costs. In spite of the underlying complexities, we could, therefore, expect that switching behavior, and hence, relationship quality (Ford, 1980) is impacted by customers' perceived influence on supplier innovation: customers who perceive that they have a high influence on their supplier's innovation activities could be expected to have more confidence into the suppliers' capabilities (Hooley et al., 1998) and could, thus, contribute positively with SOW in a remaining supplier relationship (Blut et al., 2016).

\subsection{Customer's perceived product innovativeness and loyalty}

Building upon the above rationale of customers' perceived influence on supplier innovation, and the fact that increased customer attractiveness to a focal supplier can be rationalized with attitude-behavior relations models (Ajzen and Fishbein, 1980; Eagly and Chaiken, 1993) in Anderson and Mittal's (2000) SRF, we anticipate that a customer's perception of the supplier's product innovativeness is also a relevant aspect of relationship quality (Ford, 1980; Dorsch et al., 1998). In particular, we expect that raising relationship quality - here through the perceived quality of the focal supplier's product innovativeness from a customer's perspective - may not only impact customer and employee engagement (Anaza and Rutherford, 2012; Kumar and Pansari, 2016a) but also entice the customer to allocate a greater share of its purchases to a given focal supplier (Rauyruen and Miller, 2007; Čater and Cater, 2010). In spite of these complexities and in light of the absence of empirical evidence on how customers' perceived product innovativeness relates to behavioral loyalty, we may nevertheless expect that distinct combinations of innovativeness-measures may lead to higher behavioral loyalty, in line with Anderson and Mittal's (2000) SRF and its adaptation to SOW.

\subsection{Perceived customer orientation and customer account profitability}

The overriding objective in customer orientation is the maximization of appropriable value creation relative to competition (Narver et al., 1990; Jaworski and Kohli, 1993; Foss and Lindenberg, 2013). The review of Zablah et al. (2004) on customer relationship management (CRM) work has essentially established that CRM success cannot be achieved without customer orientation. Customer orientation has been viewed as a key component of the higher-order construct relationship quality (Dwyer et al., 1987; Dorsch et al., 1998; Viio and Grönroos, 2016), contributing to value creation in B2B relationships from the customer's perspective (Jolson, 1997; Singh and Koshy, 2011). Such value creation through customer orientation can be a function of market orientation (Narver et al., 1990; Payne and Holt, 2001; Narver et al., 2004), involving the discovery of latent customer needs, and thus, potentially affecting firm performance in positive ways (Atuahene-Gima, 1995). Recent work puts forward more evidence for the link between customer engagement and performance of the focal firm (Harmeling et al., 2017; Pansari and Kumar, 2017), consolidating earlier evidence that customer orientation matters for supplier performance. This evidence originates from double-dyad interviews of Japanese firms (Deshpandé et al., 1993), as well as from a study of UK small and medium size enterprises's, which identifies a positive relationship between 
customer orientation and profitability (Appiah-Adu and Singh, 1998). Other work suggests that customer orientation can significantly enhance the performance of manufacturing and service firms as part of supplier collaboration (Atuahene-Gima, 1996; Wang et al., 2016a). Further evidence using a fuzzy set analysis reinforces the notion that highly performing firms configure themselves around their customer orientation (Frambach et al., 2016). The overall empirical evidence for a positive relationship between customer orientation and firm performance can be motivated by Anderson and Mittal's (2000) framework underlying the satisfaction-repurchase-profitability sequence (Keiningham et al., 2005; Cooil et al., 2007) and its projections of increasing returns to higher levels of satisfaction (Mittal and Kamakura, 2001). In light of our particular interest in perceived customer orientation of the supplier from the perspective of the buyer, the literature has highlighted varying definitions and measurement methods of customer orientation as a function of the firm perspective (Woodruff, 1997) and the customer perspective (Eggert and Ulaga, 2002; Stępień, 2017), highlighting the complexities underlying these antecedents of performance outcomes (Mittal et al., 2018).

\subsection{Perceived product innovativeness and customer account profitability}

Analyzes focusing on a supplier's innovativeness as perceived by its customers have received far less attention compared to analyzes focusing on the role of supplier perceptions of innovation related to financial performance in supplier-buyer relationships (Ellis et al. (2012) and Jean et al. (2014) for evidence from the automobile sector; Wang et al. (2016a) for evidence from Chinese enterprises). This is somewhat surprising in the face of a growing literature on the measurement of customer-perceived value (Ulaga and Chacour, 2001; Ulaga, 2003; Ritter and Walter, 2012; Stępień, 2017). It is also surprising, since the conceptual analysis by Sampson and Spring (2012) has put forward an extended-capabilities view of customers as a basis for supplier-customer innovation in supply chains. Furthermore, the lack of research focus on innovativeness as perceived by customers may also be striking, as recent work has highlighted that the outcome from customization depends also on perceived customer participation (Wang et al., 2016b). Yet, what does previous research suggest on the complex relationship between customer-perceived benefits related to innovation, relationship value and financial performance? Considering a supplier's product innovativeness as perceived by its customers, the creation of relationship value is likely a function of both customer-perceived benefits and costs of a supplier relationship (Ulaga and Eggert, 2006; Blocker et al., 2011; Lindgreen et al., 2012). Having created such relationship value, customer value could be expected to drive customer share (Cannon and Homburg, 2001; Eggert and Ulaga, 2010). Furthermore, from Eggert and Ulaga's (2010) view of customer value being a fundamental driver of customer share in business markets, we could conjecture that customer value (and perceived product innovativeness of the supplier, in our case) could also be expected to be positively associated with account profitability, as long as customers can appropriate some returns to higher supplier product innovativeness. More specifically, we might expect participation of customers in innovative practices to come at a high marginal cost to suppliers and customers early on in building and coordinating a supplier-customer relationship (Almirall and Casadesus-Masanell, 2010; Greer and Lei, 2012), but then to lead to increasing returns to customer investments in relationship value in the longer term (Mittal and Kamakura, 2001; Homburg et al., 2005). Such nonlinearity might also be expected from Ritter and Walter's (2012) analysis of perceptual data from a sample of German firms, as this analysis suggests that change-related relationship functions, including customer innovativeness, can have a non-linear impact on relationship value. Taking the above rationale into account, and invoking Anderson and Mittal's (2000) 
$\mathrm{EJM}$

55,13

framework underlying the satisfaction-repurchase-profitability sequence (Keiningham et al., 2005; Cooil et al., 2007), we could expect that the extent to which customers perceive that they can influence a supplier's product innovativeness is reflected in the profitability of customer accounts. However, given the underlying complexities with respect to the possible paths that can lead to the same profitability outcome, it is not clear whether such innovativeness perception is positively reflected in the outcome measure as a function of increasing returns to relationship investment.

\subsection{Propositions development}

The following proposition development centers on the two key outcome measures that we aim to investigate as part of Anderson and Mittal's (2000) SRF and its adaptation to SOW (Keiningham et al., 2005; Cooil et al., 2007). As the literature discussed above highlights, the impacts of individual perceptual customer constructs on the two outcome measures under investigation (SOW and customer account profitability) are potentially complex, as one might mute the potential impact of another, and considering that higher levels of perceptual constructs may not necessarily lead to higher levels of outcome (SOW and profitability). This conclusion applies in particular to our central tenet, namely, Anderson and Mittal's (2000) SRF, as it has received both support from studies that put forward a positive association between attitudinal loyalty and customer profitability (Reichheld, 1996; Reichheld et al., 2000), and lack of support from studies pointing to weaknesses in the association between attitudinal loyalty and profitability (Ganesan, 1994; Dowling and Uncles, 1997; Söderlund and Vilgon, 1999), pointing to further complexities underlying the customer perception implications in this context (Parasuraman et al., 2020). Following applications of complexity theory (Spivack and Woodside, 2019; Wu et al., 2016; Gounaris et al., 2016; Woodside, 2015), we, therefore, need to take into account:

- that varying components in a "recipe" can positively or negatively impact the outcome condition as a function of the presence or absence of other components in the recipe;

- that combinations of elements are needed, such that single components can be necessary but not necessarily sufficient to predict a given outcome variable; and

- that the same outcome variable can be achieved through multiple paths in terms of different combinations of attributes in a recipe.

As we aim to assess through a configuration analysis to what extent a combination of attributes (perceptual customer constructs) discussed above lead to the same outcomes (SOW and profitability), we propose the following propositions in line with previous related analyzes (Russo et al., 2016; Gligor et al., 2019):

P1a. An individual attribute in a recipe can contribute positively or negatively to behavioral loyalty, as a function of the presence or absence of other ingredients in the recipe (attitudinal loyalty, perceived customer orientation, perceived innovativeness of the supplier and perceived customer influence on supplier innovation).

P1b. An individual attribute in a recipe can contribute positively or negatively to customer account profitability, as a function of the presence or absence of other ingredients in the recipe (attitudinal loyalty, perceived customer orientation, perceived innovativeness of the supplier and perceived customer influence on supplier innovation). 
P2a. Simple antecedent conditions (attitudinal loyalty, perceived customer orientation, perceived innovativeness of the supplier and perceived customer influence on supplier innovation) can be necessary but insufficient for high behavioral loyalty.

Behavioral outcomes

P2b. Simple antecedent conditions (attitudinal loyalty, perceived customer orientation, perceived innovativeness of the supplier and perceived customer influence on supplier innovation) can be necessary but insufficient for high customer account profitability.

P3a. Disparate configurations of perceptual customer attributes (attitudinal loyalty, perceived customer orientation, perceived innovativeness of the supplier and perceived customer influence on supplier innovation) are equifinal in leading to high behavioral loyalty.

P3b. Disparate configurations of perceptual customer attributes (attitudinal loyalty, perceived customer orientation, perceived innovativeness of the supplier and perceived customer influence on supplier innovation) are equifinal in leading to high customer account profitability.

\section{Methods}

\subsection{Data and descriptive statistics}

Our database for the subsequent analysis is comprising two data sets, one perceptual data set and a second one containing information on net sales, gross profit, sales cost and actual quantities sold. The perceptual data used comes from an international B2B customer survey conducted by and outsourced to an international marketing firm with expertise in marketresearch (it is ISO27001 and ISO9001 certified and a member of European Society for Opinion and Market Research), on behalf of the focal multinational mechanical engineering firm. First, the survey pre-development included several workshops with participating focal company representatives (senior marketing managers), representatives from the marketresearch company and selected $\mathrm{B} 2 \mathrm{~B}$ company representatives (i.e. existing customers of the multinational focal company, representing different customer sizes). The survey was emailed out by the market-research company during the period January 23rd to February 15th, 2013 (proportional-stratified sampling). The survey was targeted to existing customers from seven countries (UK, Belgium, China, Denmark, Switzerland, Turkey and Finland), who were asked to reply to 54 technology and marketing-related questions, from which we have drawn all perceptual constructs for the subsequent analysis. Table 1 displays the perceptual measures and the underlying survey questions. Table 2 shows the corresponding

\begin{tabular}{ll}
\hline Perceptual construct & Item $^{\text {a }}$ \\
\hline Customer satisfaction & How satisfied are you with X overall? \\
Attitudinal loyalty & I wish to continue using X as a supplier for my \\
& future business \\
Perceived customer orientation (CO) & Xis a customer-oriented company that understands \\
& my business \\
Product innovativeness (PI) & X develops innovative products \\
Customer influence on innovation (CI) & Ihave an opportunity to influence the development \\
& of future X products, solutions and services
\end{tabular}

Note: ${ }^{\text {aThe }}$ The of $\mathrm{X}$ stands for the name of the focal company

Table 1.

Perceptual constructs used for analysis 
$\mathrm{EJM}$

55,13

\section{2}

Table 2.

Descriptive statistics of perceptual data $(n=987)^{*}$ items and descriptive statistics. As Table 2 also shows, overall satisfaction and attitudinal loyalty are scoring highest, and customers perceive their influence on supplier innovation (PI) the lowest.

From the total of 5,992 customers that were contacted, $21 \%$ responded, resulting in a sample size of 1,229 responses [3]. To address common variance bias (CVB) (Podsakoff et al., 2003), we implement the Harman single-factor test (Appendices A1 and A2). This test indicates that common method bias has not overly influenced survey participants' responses, as the total variance explained by a single factor did not pass the threshold of 50\% (Malhorta et al., 2006, 2017). Notably, as we are merging survey responses with archival performance metrics obtained from the focal multinational supplier, the measures that are used for our analysis are not only perceptual constructs but also objective measures, which is relevant in regard to CVB, as Chang et al. (2010) highlight that the CVB concern is strongest when both the dependent and focal explanatory variables are perceptual measures derived from the same respondent.

The correlation matrix (Table 3 ) suggests that questions, which are concerned with the perception of the supplier correlate on a significant level ( $\alpha<0.01$, two-tailed) to a different but exclusively positive degree. This does, however, not apply to SOW (measured in terms of customers' percentage of total procurement within the past year purchased from the focal supplier), which does not correlate significantly with several of the perception-related items, including perceived customer influence on supplier innovation. Further, a significant correlation with SOW can be observed for items regarding satisfaction and attitudinal loyalty, though at relatively low levels.

\begin{tabular}{lrrrcrr}
\hline Item & Mean & SD & Skew & Kurtosis & Min & Max \\
\hline Customer satisfaction & 8.30 & 1.50 & -1.87 & 8.07 & 1 & 10 \\
Attitudinal loyalty & 8.74 & 1.49 & -1.99 & 8.50 & 1 & 10 \\
Perceived customer orientation (CO) & 8.16 & 1.63 & -1.49 & 6.14 & 1 & 10 \\
Product innovativeness (PI) & 8.13 & 1.41 & -1.07 & 4.98 & 2 & 10 \\
Customer influence on innovation (CI) & 6.83 & 2.18 & -0.89 & 3.45 & 1 & 10 \\
SOW & 60.41 & 36.21 & -0.3898 & 1.534 & 0 & 100
\end{tabular}

Notes: ${ }^{* * * *}$ Questionnaire scales ranging from 1-10 for all items. SOW measured on a scale from 0 to 100
Table 3.

Correlation matrix

\begin{tabular}{|c|c|c|c|c|c|c|c|}
\hline Constructs & 1 & 2 & 3 & 4 & 5 & 6 & 7 \\
\hline Customer satisfaction & $1.000 \mathrm{x}$ & & & & & & \\
\hline Attitudinal loyalty & $0.584^{* *}$ & $1.000 \mathrm{x}$ & & & & & \\
\hline Perceived customer orientation & $0.599^{* *}$ & $0.551^{* * *}$ & $1.000 \mathrm{x}$ & & & & \\
\hline Perceived innovativeness & $0.559^{* * *}$ & $0.571^{* * *}$ & $0.626^{* *}$ & $1.000 \mathrm{x}$ & & & \\
\hline Perceived innovation influence & $0.337^{* *}$ & $0.328^{* * *}$ & $0.432^{* *}$ & $0.461^{* *}$ & 1.000 & & \\
\hline Share of wallet & $0.200^{\text {*** }}$ & $0.234^{* *}$ & $0.160^{* *}$ & $0.129^{* * *}$ & 0.034 & $1.000 \mathrm{x}$ & \\
\hline Fractional profitability & $-0.047 \mathrm{x}$ & $-0.032 \mathrm{x}$ & $-0.048 \mathrm{x}$ & $-0.018 \mathrm{x}$ & 0.011 & $-0.206^{* *}$ & 1.000 \\
\hline Mean & $8.302 \mathrm{x}$ & $8.739 \mathrm{x}$ & $8.157 \mathrm{x}$ & 8.133x & 3.468 & $60.41 \mathrm{x}$ & 0.302 \\
\hline $\mathrm{SD}$ & $1.503 x$ & $1.789 x$ & $1.634 \mathrm{x}$ & $1.409 \mathrm{x}$ & 2.181 & $36.21 \mathrm{x}$ & 0.2386 \\
\hline
\end{tabular}


The second data set includes information on net sales, gross profit, sales cost and actual quantities sold for the year 2013. As the goods produced by the manufacturing multinational are not perishable nor needing steady replenishment, it is unsurprising that not all customers purchased goods from the focal firm during the year 2013. In the following, we present descriptive statistics for the sales data set, including information on four items, net sales, gross profit, sales cost and quantity sold. Yet, for the purpose of the following analysis, only net sales and gross profits are used to calculate the fractional profit, as it is a metric incorporating both profit and total sales. This profitability ratio is considered for analyzing performance, since it includes the trade-off between sales costs and profitability:

$$
\frac{\text { gross profit }}{\text { net sales }}=\text { profitability ratio }
$$

As Table 4 shows, the removal of two outliers (excluding outliers at $p=0.01$ ) reduces standard deviation, skew and kurtosis significantly. Thus, the fractional profit with outliers at the 0.99th percentile removed is used for the remainder of the analysis. The final table of descriptive statistics matching the sales data set with the stated preference data (Table 5 , $n=616$ ) suggests a positive view of the focal supplier: with the mean at 0.3 , a slightly negative skew implies that the majority of entries are distributed higher in the increasingly profitable half of the spectrum.

\subsection{Analysis}

The following analysis implements a fsQCA modeling approach (Spivack and Woodside, 2019; Wu et al., 2016; Ragin and Davey, 2016), with the aim of uncovering complex relationships underlying the constructs developed above as part of the propositions. FsQCA is a set-theoretic research method that explains combinations of factors (causal attributes, termed conditions, such as customer satisfaction) that generate the same result, e.g. customer account profitability (Ragin, 2009; Gligor et al., 2019). Qualitative comparative

\begin{tabular}{lllllr}
\hline Profitability ratio & $N$ & Mean & SD & Skew & Kurtosis \\
\hline All entries & 618 & 0.4171 & 3.18 & 24.25 & 598.7 \\
Outlier removal & 616 & 0.302 & 0.2386 & -0.059 & 5.836
\end{tabular}

Notes: ${ }^{* *}$ Outliers are removed at the 99 th percentile using the Mahalabonis distance-based procedure (using the STATA plugin by Weber (2010)). The removal of only two outliers reduces standard deviation, skew and kurtosis significantly. With the mean at 0.3 , a slight negative skew implies that the majority of entries is distributed in the increasingly profitable half of the spectrum
Behavioral outcomes

\begin{tabular}{|c|c|c|c|c|c|c|c|}
\hline Item & Mean & SD & Skew & Kurtosis & Min & Max & \\
\hline Customer satisfaction & 8.30 & 1.41 & -1.89 & 8.16 & 1 & 10 & \\
\hline Attitudinal loyalty & 8.77 & 1.37 & -1.84 & 7.67 & 2 & 10 & \\
\hline Perceived customer orientation (CO) & 8.13 & 1.59 & -1.48 & 6.14 & 1 & 10 & Descriptive statistics \\
\hline Product innovativeness (PI) & 8.13 & 1.34 & -0.98 & 4.69 & 2 & 10 & matching sales data \\
\hline Customer influence on innovation (CI) & 6.82 & 2.13 & -0.92 & 3.70 & 1 & 10 & with perceptual data \\
\hline Behavioral loyalty (SOW) & 60.70 & 35.11 & -0.38 & 1.59 & 0 & 100 & $(n=616)$ \\
\hline
\end{tabular}


$\mathrm{EJM}$

55,13

analysis (QCA) research has recently expanded almost exponentially in business and management research (Russo et al., 2016; Wagemann et al., 2016; Gounaris et al., 2016; Spivack and Woodside, 2019; Gligor et al., 2019), building upon the pioneering work of Ragin (2009), as it can address the complexity of underlying relationships between various antecedents, and the issue that attribute metrics, which drive outcome measures (such as profitability) can depend on varying combinations of attributes. QCA enables us, therefore, to assess possible combinations of attributes, thereby determining the possible "recipes" that could lead to the same outcome (equifinality), in particular for complex cases where X can have a positive impact on $\mathrm{Y}, \mathrm{X}$ a negative impact on $\mathrm{Y}$ and $\mathrm{X}$ and $\mathrm{Y}$ share no relationship (Russo et al., 2016; Gligor et al., 2019).

The benefit relative to multivariate regression methods is, thus, that asymmetric and complex relationships underlying the above constructs can be uncovered (Russo et al., 2016; Rihoux and Ragin, 2008). This arises because the fsQCA approach assumes that the influence of attributes - e.g. customer satisfaction - on a specific outcome (customer account profitability, in our case) depends on how different attributes are combined with each other (Russo et al., 2016), and thereby fsQCA addresses the limited focus on main "net effects" of antecedents of customer loyalty or other B2B constructs observed in multiple regression analysis (Spivack and Woodside, 2019; Wu et al., 2016; Russo et al., 2016).

In our application of fsQCA, we follow primarily Ragin (2009) [4], Russo et al. (2016) and Maggetti and Levi-Faur (2013). In following Russo et al. (2016) and Russo and Confente (2019), we first check the appropriateness of applying QCA through contrarian cases (crosstabulations), and then define the property space, in terms of possible configurations of drivers of the outcome measure. The property space is defined through the calibration of partial memberships in sets (Rihoux and Ragin, 2008), partitioning the membership into meaningful groupings by using values between zero (no membership) and one (full membership). Since we are interested in improving our understanding of Anderson and Mittal's (2000) SRF and its adaptation to SOW (Keiningham et al., 2005; Cooil et al., 2007), we focus on two outcome measures, namely, behavioral loyalty (SOW) and account profitability. Taking into account our propositions as developed in Section (2), we focus on four potential outcome drivers, namely, attitudinal loyalty, customers' perceived influence on supplier innovation, customers' perceived product innovativeness of the supplier and perceived customer orientation.

To first assess the appropriateness of QCA and illustrate the complexity underlying the outcome measures of interest, we follow Russo and Confente (2019) in implementing a contrarian case analysis. We, therefore, provide two sets of cross-tabulations between outcomes and antecedents, for both of our outcome measures, behavioral loyalty and profitability (Appendix A3) [5]. Following Russo and Confente (2019), we find the existence of contrarian cases by building a contingency table, suggesting that in some cases low degrees of customer perceptions lead to high outcomes (SOW and profitability), while in others high degrees of customer perceptions lead to a low degree of behavioral loyalty and profitability, as reflected in the rather even distribution of output levels over the quintiles of the perceptual measures.

In the next step, these four items are re-coded from a Likert-type scale to continuous variables $(0-1)$. The task involved in this re-coding is akin to calibration to transform variables into sets with three anchors (full set membership, crossover point and nonmembership), as a basis to convert our Likert-type scales into fuzzy-set membership, so that these fuzzy sets permit the scaling of membership scores and allows partial membership. Following Wu et al. (2016) and Spivack and Woodside (2019), thresholds were set at 0.05 for non-membership, 0.5 as the crossover point, and 0.95 for full membership in our 
constructs [6]. Truth tables are constructed next (Tables 6 and 8), to define the property space, reflecting the assessment of combinations empirically present in our data, where 0 is given to an attribute in case of its absence and 1 is assigned in case of its presence. To explore these combinations of the four potential outcome drivers that are consistent according to set theory (Russo et al., 2016), we consider fuzzy set membership scores in the interval 0 to 1 for both profitability (Table 6: antecedent conditions for high scores in the profitability of different customer accounts) and for SOW (Table 8: Antecedent conditions for high scores in behavioral loyalty). We follow the recommendation by Maggetti and LeviFaur (2013) and use a frequency cut-off of 3 for the truth-table, given our sample size of $n \geq$ 50 (Greckhamer et al., 2013), and then assign membership to profitability at a consistency level $\geq 0.8$, i.e. we set the lowest acceptable consistency score at 0.80 , which is above the minimum recommended threshold of 0.75 (Timmer and Kaufmann, 2019: 0.8; Greckhamer et al., 2013: $\geq 0.8$, Spivack and Woodside, 2019: 0.75). We are next interested in assessing the robustness of fuzzy-set fsQCA results through three tests of robustness, starting with consistency (Skaaning, 2011; Ragin, 2012; Schwellnus, 2013) [7]. Varying the cross-over points of the fuzzy set yields comparable results to the original truth table, implying a high degree of robustness of the results. The second robustness check involves testing the same model on the negated outcome (profitability: Table 7; SOW: Table 9) (Skaaning, 2011),

\begin{tabular}{llllllllllllll}
\hline $\begin{array}{l}\text { Attitudinal loyalty (LOY) } \\
\text { Perceived customer orientation (CO) }\end{array}$ & $\bullet$ & $\bullet$ & $\bullet$ & $\bullet$ & $\otimes$ & $\bullet$ & $\otimes$ & $\otimes$ & $\otimes$ & $\otimes$ & $\bullet$ \\
Product innovativeness (PI) & $\otimes$ & $\otimes$ & $\bullet$ & $\otimes$ & $\otimes$ & $\bullet$ & $\otimes$ & $\bullet$ & $\bullet$ & $\otimes$ & $\bullet$ \\
Customer influence on innovation (CI) & $\bullet$ & $\otimes$ & $\otimes$ & $\bullet$ & $\otimes$ & $\otimes$ & $\bullet$ & $\bullet$ & $\bullet$ & $\otimes$ & $\bullet$ \\
Profitability & $\bullet$ & $\bullet$ & $\bullet$ & $\bullet$ & $\bullet$ & $\bullet$ & $\bullet$ & $\bullet$ & $\otimes$ & $\otimes$ & $\otimes$ \\
Number & 3 & 6 & 4 & 4 & 3 & 8 & 3 & 5 & 6 & 41 & 77 \\
Raw consistency** & 0.83 & 0.83 & 0.83 & 0.81 & 0.81 & 0.81 & 0.81 & 0.80 & 0.79 & 0.77 & 0.72 \\
PRI consistency & 0.24 & 0.28 & 0.24 & 0.26 & 0.30 & 0.30 & 0.31 & 0.28 & 0.33 & 0.33 & 0.27 \\
SYM consistency & 0.24 & 0.28 & 0.24 & 0.26 & 0.30 & 0.30 & 0.31 & 0.28 & 0.33 & 0.35 & 0.32
\end{tabular}

Notes: (**for further interpretation of raw consistency, the "proportional reduction in consistency" (PRI) measure and symmetric (SYM) consistency see Ragin (2012) and Schwellnus (2013)). $\otimes$ Causal condition absent. $\bullet$ Causal condition present
Behavioral outcomes

Table 6.

Configurations for achieving high profitability of different customer accounts

\begin{tabular}{|c|c|c|c|c|}
\hline \multicolumn{5}{|c|}{$\begin{array}{c}\text { Main configurations for profitability of a customer's account } \\
\text { Solutions }\end{array}$} \\
\hline & 1 & 2 & 3 & 4 \\
\hline Attitudinal loyalty (LOY) & & $\otimes$ & - & $\bullet$ \\
\hline Perceived customer orientation (CO) & $\bullet$ & $\otimes$ & & \\
\hline Product innovativeness (PI) & $\otimes$ & & $\bullet$ & $\otimes$ \\
\hline Customer influence on innovation (CI) & $\otimes$ & $\bullet$ & $\otimes$ & $\bullet$ \\
\hline Consistency & 0.81 & 0.80 & 0.80 & 0.80 \\
\hline Raw coverage & 0.49 & 0.38 & 0.56 & 0.47 \\
\hline Unique coverage & 0.032 & 0.04 & 0.10 & 0.04 \\
\hline Solution coverage & 0.71 & & & \\
\hline Solution consistency & 0.75 & & & \\
\hline
\end{tabular}

Notes: (*** for more detailed interpretation of truth tables: Ragin (2012)). $\otimes$ Core causal condition absent. - Core causal condition present
Table 7.

Configurations for profitability of a customer's account*** 
EJM

55,13

16

confirming symmetry of the results. Following Ragin and Fiss (2008), black circles indicate the presence of a condition while crossed circles indicate its absence, and blank cells indicate that the condition is not considered in the solution. Table 6 shows 33 cases of positive association between profitability and individual perceptual items.

We note that consistency and coverage are metrics indicating the usefulness of a given model of a simple antecedent condition or a set of complex antecedent conditions (Tables 6 and 8) for predicting scores in an outcome condition (Spivack and Woodside, 2019). While coverage is akin in interpretation to $R^{2}$ in multivariate regression analysis, it measures the share of consistent memberships as a proportion of the total membership in the outcome set, hence helps to determine, which percentage of the outcome is covered through a solution (Ragin, 2006; Russo and Confente, 2019). In contrast, consistency measures the degree to which the cases share a simple or a complex antecedent condition in displaying our outcome of interest (Gounaris et al., 2016). As a next step, truth-table algorithms (Quine-McCluskey algorithms; Ragin, 2009) are, therefore, used with profitability (Table 7) and behavioral loyalty (Table 9) set as the outcome variable, respectively, and attitudinal loyalty, customer orientation, influence on innovation and perceived innovativeness as antecedents to assess coverage and consistency of the resulting recipes. As Table 7 shows, we distinguish the consistency of the total solution (0.75) and consistency of the four combinations (0.71). In studying the main configurations (Tables 7 and 9), we anticipate to observe cases whereby an antecedent condition associates with the two outcome conditions under investigation in a manner potentially counter to the reported principal symmetric relationship (Wu et al., 2016), as outlined by our propositions.

In summary, and as Table 7 shows, raw coverage and unique coverage suggest that the configural statements are empirically relevant to varying degrees (Ragin, 2009). [8] While individual recipe configurations are associated with a high outcome, our data does not suggest a uniform solution, nor that association with all perceptual measures involved necessarily is associated with a high outcome. Instead, we find that the presence of perceived customer orientation, and absence of perceived innovativeness and perceived influence on innovation is providing the highest consistency and raw coverage metrics (Solution 1), while the presence of attitudinal loyalty, perceived innovativeness and absence of perceived influence on innovation is providing the highest unique coverage.

To investigate matters further, a second truth table was generated only with our perceptual constructs (attributes), and with behavioral loyalty (SOW) as the outcome condition, to investigate $P 2$ and $P 3$ (Tables 8 and 9). Again, we find limited evidence of interconnectedness, as consistency scores in the truth table are below the recommended 0.8 threshold. Interestingly, Table 9 is essentially suggesting the same recipe configurations as Table 7 , while the most parsimonious solution is simply showing a negative association

Table 8.

Configurations for achieving high scores of behavioral loyalty (SOW)

Attitudinal loyalty (LOY)
Perceived customer orientation (CO)
Product innovativeness (PI)
Customer influence on innovation (CI)
Behavioral loyalty (SOW)
Number
Raw consistency**
PRI consistency
SYM consistency

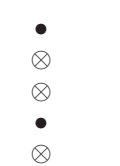

19

0.77

$0.61 \quad 0.59$

$0.63 \quad 0.59$

$\bullet$
$\otimes$
$\otimes$
$\otimes$

79

0.74

0.61

0.62

$\bullet$
$\bullet$
$\otimes$

13

0.72

0.55

0.55

$\bullet$
$\bullet$
$\bullet$
$\otimes$
7
0.71
0.54
0.54

$\begin{array}{cc}\bullet & \bullet \\ \bullet & \bullet \\ \otimes & \bullet \\ \otimes & \otimes \\ 61 & 197 \\ 0.64 & 0.58 \\ 0.49 & 0.45 \\ 0.49 & 0.47\end{array}$

Notes: $\otimes$ causal condition absent. $\bullet$ Causal condition present 
between attitudinal loyalty and behavioral loyalty, albeit still at coverage levels of 0.52 and consistency levels at 0.63 . Furthermore, as Table 10 suggests, a reduction in the consistency level to the minimum of 0.75 as suggested by Spivack and Woodside (2019), does yield a truth table indicating a positive association between attitudinal loyalty, customer influence on innovation and behavioral loyalty as the outcome, albeit at the obvious trade-off with regard to the robustness of the solution.

\subsection{Discussion of results}

When considering all of the above fsQCA results in the context of Anderson and Mittal's (2000) SRF and its adaptation to SOW (Keiningham et al., 2005; Cooil et al., 2007), it is striking that our analysis indicates a lack of a clear connection between the discussed perception metrics, in particular attitudinal loyalty, and SOW. Considering the truth table for profitability (Table 7), we find evidence for potential non-linearities between the profitability of a customer account and perceptual metrics. Indeed, customers who score the highest across all reported perceptual metrics cannot be clearly associated with a high profitability outcome. However, none of the perceptual metrics could be excluded from being potentially associated with a high profitability outcome either.

In other words, the results suggest that profitability does not have a "symmetric" relationship with attitudinal loyalty, perceived customer orientation, perceived influence on innovation and perceived innovativeness. Nevertheless, different configurations of the

\begin{tabular}{|c|c|c|c|c|}
\hline Configurations & $\begin{array}{c}\text { Solutions } \\
1\end{array}$ & 2 & 3 & 4 \\
\hline Attitudinal loyalty (LOY) & & $\otimes$ & - & - \\
\hline Perceived customer orientation (CO) & $\bullet$ & $\otimes$ & & \\
\hline Product innovativeness (PI) & $\otimes$ & & - & $\otimes$ \\
\hline Customer influence on innovation (CI) & $\otimes$ & - & $\otimes$ & - \\
\hline Consistency & 0.69 & 0.78 & 0.64 & 0.72 \\
\hline Raw coverage & 0.25 & 0.21 & 0.35 & 0.28 \\
\hline Unique coverage & 0.04 & 0.01 & 0.10 & 0.07 \\
\hline Solution coverage & 0.51 & & & \\
\hline Solution consistency & 0.62 & & & \\
\hline
\end{tabular}

Notes: $\otimes$ core causal condition absent. $\bullet$ Core causal condition present

\section{Behavioral outcomes}


$\mathrm{EJM}$

55,13

18

perceptual metrics, such as the presence of customer orientation and the absence of perceived innovativeness and perceived influence on innovation can still be associated with high levels of profitability for a given customer account.

Furthermore, since our paper started out by aiming to also contribute to the literature on value-in-use in the context of customer loyalty, we need to consider the above findings also in the context of the value-in-use literature. First, building on the finding by Macdonald et al. (2016) that customers also assess the quality of the joint resource integration process with their supplier, we could conjecture that perceptual measures associated with innovation investigated here are largely irrelevant to customers for assessing the quality of this joint resource integration process, except for perceived innovativeness in the context of profitability. Second, if we view value-in-use as inherently multidimensional due to the diversity of customer goals (Macdonald et al., 2016), our results could be interpreted such that other dimensions matter more to customers relative to perceptual innovation measures. For example, Sirdeshmukh et al. (2002) investigated one particular dimension of value-in-use with regard to value perceived through service delivery. Similarly, we could take the multidimensionality of the definition of value-in-use with regard to all customer-perceived consequences (Macdonald et al., 2016), to argue that perceptual innovation measures investigated here reflect only one dimension of value perception, hence that other customerperceived consequences are more relevant than those associated with innovation (e.g. perceived risk of supply chain disruption). Consider also that this multi-dimensionality of value-in-use has been further elaborated by Grönroos (2011, p. 242), who distinguishes three dimensions of what value a customer can create out of the support provided by a supplier. First, the effects on the customer's growth- and revenue-generating capacity; second, the effects on the customer's cost level; and third, effects on perceptions. Among these effects on perceptions, Grönroos (2011) distinguishes four dimensions, namely, increased trust in the supplier, increased commitment to the supplier, increased comfort in supplier interactions and increased attraction of the supplier. In our case, if we consider the support provided by the focal supplier in terms of innovation-related feedback mechanisms (the potential for participatory innovation as reflected in a customers' perceived influence on supplier innovation, and customers' perceived product innovativeness of the supplier), it seems that in the case of our focal globalized supplier, none of the four dimensions put forward by Grönroos (2011) have been affected positively by affiliating customers more closely with the supplier's innovation value chain (trust, commitment, comfort and attraction). In other words, the evidence from configuration analysis that individual innovation-perceptionrelated attributes are largely insufficient for high behavioral loyalty or high customer account profitability could be viewed as an indication that customers perceive limited value in participating in the focal firm's innovation value chain (funnel).

Furthermore, when we consider these results regarding perceptual customer constructs of innovation as derived from the globalized industrial manufacturing sector, the question is how they contrast with results derived from service sector firms. Previous service sector analyzes (Kelly, 1992; Hartline et al., 2000; Alam and Perry, 2002) suggest that customer orientation plays a more important role to service firms, relative to tangible product firms. Further, if we consider not only the nature of the industry (service versus manufacturing) but also the nature of the very manufacturing sector itself, our results may be interpreted in the context of Bowen et al.'s (1989) classic analysis of customer orientation in the manufacturing sector. In the context of Bowen et al.' (1989) Proposition 1, for manufacturing firms in mature markets, the technical dimensions of customer service may be less important in attaining competitive advantage than for manufacturing firms in emerging or growth markets. 
Bowen et al. (1989, p. 87) suggest that mature markets may limit the significance of the technical dimension of customer service, such as repair services, but enhance the significance of relational dimensions, such as those where customers suggest new product designs and applications. If we consider our empirical evidence from a focal multinational manufacturing firm operating in mature markets, then our conclusion that perceived customer influence on supplier innovation by itself is largely an irrelevant relational attitude dimension with respect to the outcome variable behavioral loyalty would seem to go counter Bowen et al.'s (1989) Proposition 1. Furthermore, it is of interest to contrast this conclusion with Bowen et al.'s (1989, p. 88) second proposition that: extensive customer service may be required when manufacturing firms are initially entering a market and are trying to overcome the first-mover advantages held by established sellers, which is based on their rationale that in cases where services accompany products, services may reduce the purchase risk in novel markets. As our evidence comes from a long-established global manufacturing enterprise, which could be characterized as operating in highly mature markets, where limited first-mover advantages of competitors need to be overcome, our empirics seem to support the second Proposition of Bowen et al. (1989).

On the matter of lack of relevance of individual customer perceptual metrics put forward in the context of Anderson and Mittal's (2000) SRF and its adaptation to SOW (Keiningham et al., 2005; Cooil et al., 2007), the fsQCA analysis has provided us with novel insights, as it has helped to uncover underlying complexities in the relationship between perceived product innovativeness of the supplier and SOW, which could not be uncovered through modeling that focuses on main effects only. Furthermore, the fact that the same recipes (combinations of attributes) have been uncovered for both outcomes, i.e. that equifinality has been identified for both SOW and profitability, may in fact lend support to Anderson and Mittal's (2000) SRF and its adaptation to SOW.

From a practical managerial perspective, keeping in mind the nature of the industry under investigation (globalized mechanical engineering), the overall conclusion from fsQCA analysis that equifinality does not necessarily lead to higher outcomes (SOW and profitability) may partly be explained by the fact that the product outputs from this industry have typically a longer shelf life and life cycle (compared to, say, information technology software), hence the frequency of re-purchases is likely lower and the role of customer orientation potentially less relevant in spite of high customer account profitability.

From a practical management perspective, we conclude that B2B customers investigated here value the independence between them and their supplier in the innovation funnel more, compared to their potential influence (costs) on and in the innovation funnel. In other words, those customers who perceive to have a great degree of influence on the supplier's innovation funnel may place more confidence into their own perceived innovation-related capabilities and value-in-use, rather than into the supplier's ability to drive the innovation funnel in conjunction with customers' influence on supplier innovation.

\section{Conclusions}

This study has explored the role of configurations of relationship quality dimensions for explaining sources of behavioral outcomes in the globalized manufacturing industry. We started from the premise that in spite of extensive work on perceptual customer constructs, and a detailed understanding of the multi-dimensional nature of customer engagement, we still lack understanding of customer engagement in those applications of customer engagement where perceptual constructs are directly incorporated into behavioral outcomes (Gupta and Zeithaml, 2006; Kumar et al., 2013; Vivek et al., 2019). Furthermore, in these applications, we are missing a deeper understanding of combinations of antecedents, to 
EJM

55,13

explain behavioral outcomes in globalized manufacturing through alternate approaches to main-effects focused analyzes. We, therefore, use QCA using fuzzy sets (fsQCA) (Russo and Confente, 2019) to address these gaps, focusing on two key behavioral outcomes, namely, customer account profitability and SOW. Conceptually, our study draws from Anderson and Mittal's (2000) framework underlying a satisfaction-repurchase-profitability sequence and its adaptation to SOW (Keiningham et al., 2005; Cooil et al., 2007). It provides evidence from the global mechanical engineering sector, contributing to our understanding of the value of customer engagement in new product development and innovation, as well as contributing to the debate on the relationship between perceptual constructs and behavioral metrics in B2B markets. Taken together, our results corroborate earlier cross-industry evidence that "more attention to perceptual constructs is not always better" in terms of supplier performance (Leverin and Liljander, 2006; Ritter and Walter, 2012; Tang and Marinova, 2020).

The fsQCA results suggest that the underlying relationships are complex and potentially non-linear and that customer perceptions of a supplier's product innovativeness may be relevant for profitability, and thus, a relevant yet limited dimension of relationship quality. We, therefore, conclude that the focal manufacturing supplier has partly been successful in supporting the customer base to create joint value (Grönroos, 2011; Grönroos et al., 2010).

Considering the extent to which customers perceive value in the opportunity to be involved in the supplier's innovation value chain, in terms of customers' perceived influence on supplier innovation, the fsQCA results suggest that when taking into account a causal asymmetric perspective, such perceptions of influence on innovation within the focal company do not matter as a relevant dimension of relationship quality. This leads us to conclude that customers may place more confidence into their own perceived innovationrelated capabilities and value-in-use, rather than into the supplier's ability to drive the innovation funnel in conjunction with customers' influence on supplier innovation. Further explanations for the lack of relevance of customer influence on supplier innovation could be drawn from the nature of the sector under investigation (globalized mechanical engineering with limited evidence of outbound open-innovation practices) and from the significant size of the focal multinational firm under investigation, as previous work has shown that inbound open innovation practices are more common than outbound practices in large firms (Chesbrough and Brunswicker, 2013).

Furthermore, considering customer perceptions of the supplier's product innovativeness in the context of SOW, the fSQCA results also point to asymmetries and complexities, yet they do not support customer perceptions of supplier innovation being relevant for relationship quality. This lack of support for the sufficiency of individual attributes, such as customers' perceived influence on supplier innovation in the recipes investigated, provides some support for the view that other values than customers' perceived influence on innovation may be more important in CRM (Smals and Smits, 2012; O'Cass and Ngo, 2012) in our globalized manufacturing industry context. Similarly, the finding that a simple innovation-related antecedent condition (customers' perceived influence on supplier innovation) can be necessary but insufficient for high behavioral loyalty may suggest that customers place greater value on other supplier competences, such as the focal firm's perceived ability to deal with customer risk concerns (Meunier, 2014), including supply disruption risks (Ellis et al., 2010). A customer's need for supply chain reliability as reflected in established products may thus, need to be counterbalanced by the perceived risk that switching to alternate suppliers (Russo et al., 2016; Chebat et al., 2011) or to more innovative products entails for customers. Such 
perceived risks (costs) of switching have been found to be increasingly important as customer-organization relationships deepen (Bell et al., 2005), and especially in the context of product innovation (Salies, 2011).

Further, our finding that distinct perceptual attribute combinations are not equifinal in leading to high profitability in globalized manufacturing could be considered in the context of earlier mixed empirical evidence from the banking, telecoms and automobile sectors, which identified both positive and negative relationships between attitudinal loyalty and profitability (Dwyer et al., 1987; Reinartz and Eisenbeiss, 2015).

\subsection{Managerial implications}

In terms of managerial implications, the results with regard to customer account profitability suggest that B2B customers investigated here may distinguish when interacting with their globalized supplier in the innovation funnel: they may see a positive customer value when the innovation is product, and thus, relation-specific, whereas they may see limited customer value when innovation is considered in more generic terms (customers' perceived influence on supplier innovation in general). The finding that single specific and product-focused perceptual innovation measures for relationship quality can be necessary but insufficient for high SOW (and of limited relevance for high profitability) to occur suggests that value-in-use in the globalized manufacturing sector is less likely generated through simple incentives and strategies that compete on price. As Edvardsson et al. (2000) have also shown, service-focused companies have natural incentives to compete on service quality attributes rather than on price, as this pays off financially. Thus, our evidence from globalized manufacturing seems to be in line with an overwhelming body of evidence (Watson et al., 2015; Kranzbühler et al., 2020; Gremler et al., 2020), suggesting that customer loyalty cannot be bought using simple incentive strategies but may be built with relational strategies (commitment, trust and satisfaction).

Further, our analysis suggests that those managers in charge of CRM in complex globalized manufacturing companies may benefit from a more detailed yet complex understanding of the relationships between perceptual innovation customer concepts and outcome measures investigated here: turning customers into performance-relevant advocates may not only require more involving relational strategies but also be also more effectively achieved through the use of big data-driven analytics (Kennedy, 2006; McCollKennedy et al., 2019). We, thus, concur with Reinartz and Eisenbeiss (2015) that the linkages in the satisfaction-loyalty-profit chain are "more complex than originally assumed," especially in practice. The implication is that a better understanding of the complex and potentially non-linear relationships between innovation-related perceptual customer concepts and behavioral metrics could contribute toward more effective customer targeting, and thus, competitive advantage, as the costs and benefits of customer engagement become more transparent and long-term engagement of customers in the innovation funnel become mutually validated.

\subsection{Limitations and directions for future research}

Our analysis faces a number of limitations, starting with its reliance on cross-sectional survey data, which does not enable us to account for feedback mechanisms, for example, arising from customer perceptions regarding innovation aspects (Smals and Smits, 2012). Future work may, therefore, more extensively focus on feedback mechanisms related to customer innovation perceptions, distinguishing specific types of user-producer interaction that have been identified by Nahuis et al. (2012), while also taking into account the types of 
$\mathrm{EJM}$

55,13

technologies that differ in the degree to which they are customizable to user demands (Nahuis et al., 2012; Wijekoon and Salunke, 2018).

Our cross-sectional approach suffers also from its implicit assumption that the underlying constructs are static, which goes counter to some evidence that conceptualizing and measuring customer-perceived value is individually, subjectively and socially constructed and evolves dynamically (Payne and Holt, 2001; Stępień, 2017; Zietsman et al., 2020). Recent works on the service-profit chain building upon longitudinal data point to such interesting potential dynamic relationships, taking into account customer perceptions of service performance (Strydom et al., 2020). Building upon these insights, future work that integrates perceptual customer metrics with financial and non-financial performance indicators could focus on such dynamically constructed customer-perceived value, thereby extending applications of episodic value co-creation further (Friend et al., 2020).

Future longitudinal research on customer-perceived value associated with innovation measures could also include an assessment of customers' perceived risks in suppliercustomer relations (Ellis et al., 2010; Meunier, 2014) via the integration of big data analytics at interconnected touchpoints, extending recent works on the role of big data analytics on customer relationship performance and sales growth (Hallikainen et al., 2020) to the context of B2B consumers' innovation and risk perceptions.

A further potential limitation arises due to the imperfect matching of the behavioral and perceptual data underlying our analysis, as the former was collected about 12 months after the latter.

Furthermore, and although we are aware that, ideally, in an analysis of perceptions and SOW, perceptions should be treated as relative in terms of accounting for the fulfilment that customers perceive from various suppliers (Keiningham et al., 2015b, 2017), data limitations have prevented us from empirically accounting for such relative constructs as the Wallet Allocation Rule (Aksoy, 2014; Keiningham et al., 2015c; Buoye, 2016; Aksoy et al., 2017).

The sector-specific nature of our data set naturally raises questions of transferability of our results (Homburg et al., 2013), an issue that nevertheless has been resolved in previous single-firm, single-industry studies (Keiningham et al., 2003). In our case, in light of the globalized mechanical engineering sector's overall and technological importance to the economy (Steiert, 2008; Gardner, 2016; EC, 2018) and considering the global reach of the customer base underlying our analysis, we consider our results relevant for a significant part of companies active in globalized industrial sectors. Nevertheless, future works on other sectors would clearly be useful for cross-industry comparison.

Furthermore, our constructs capturing customer loyalty likely have their limitations in imperfectly capturing customer loyalty, considering Watson et al.'s (2015, p. 807) conclusion that: many of the promises associated with building customer loyalty remains unrealized. We find evidence in support of the premise that this failure stems, in part, from a systematic divergence between the conceptualizations (what is customer loyalty?) and measurement (how is it measured?) of loyalty.

In particular, the lack of a multidimensional conceptualization of our perceptual customer constructs may have limited our analysis, considering also recent evidence from retail companies in the furniture sector, suggesting that the multidimensional conceptualization of relationship value explained satisfaction and loyalty levels to a greater extent than the one-dimensional conceptualization (Ruiz-Martínez et al., 2019). Therefore, future research integrating behavioral and objective performance data could broaden the input data and constructs used, and apply a multidimensional conceptualization of relationship value to provide further empirical assessments. 
As a result of the above extensions, a better understanding of perceptual B2B customer metrics may contribute toward enhancing supplier performance, as well as delivering further tangible and intangible benefits to customers.

\section{Notes}

1. The focal firm in question is a diversified mechanical engineering enterprise that shares similarities in product portfolio and global reach with companies such as Bosch Rexroth AG, Linde AG, Eaton Corporation, Parker-Hannifin Corporation or Emerson Climate Technologies.

2. Following Colquitt and Zapata-Phelan (2007) and Bacharach (1989), this involves drawing on existing theory guiding us toward the development of propositions. In reviewing trends in theory building in management research, Colquitt and Zapata-Phelan (2007, p. 1285) highlight: "empirical articles that follow the inductive model do not include a priori hypotheses as a starting point, instead emphasizing the creation of propositions that can be tested in future studies."

3. The initial phase of survey pre-development and workshops led to the identification of those customers that would subsequently be targeted for surveying, notably as a function of the importance of customers during the past three years (in terms of sales average across the past three years). This led to the fact that, in several cases, multiple company representatives were contacted to represent a given customer firm, hence that multiple responses are associated with a given customer. Because of the central role of SOW in the following analysis, we only considered a sub-sample of these 1,229 ID's, namely, those who had provided SOW information (in conjuntion with all other perceptual constructs used in the following analysis), resulting in 987 ID's. For the subsequent analysis, we then merged the survey data set with the sales data set via uniquely identified individual ID's, resulting in 618 joint datapoints, which reflect the varying relative importance of customer firms. Thus, in the merged data set, which is based on 618 datapoints (cutomer firms), we consistently used simple averaging across the ID's that belong to a given customer, to place equal weight to each representative of a given customer firm. This averaging reflects, therefore that in several cases multiple employees (i.e. multiple contact points associated with given customer firm), and hence, multiple decision-makers responsible for purchasing decisions are behind the perceptual constructs of the 618 customer datapoints, contributing thereby to reducing CVB (Podsakoff et al., 2003; Chang et al., 2010). When there were missing responses in the survey data set, we used a simple imputation method (sample mean for the respective questions), following Enders (2010). Considering the descriptive statistics for pre- and postimputation (not shown here, available from the authors upon request), there is evidence for overall consistency after applying this imputation.

4. www.socsci.uci.edu/ $\sim$ cragin/fsQCA/

5. The software SPSS provides this calculation via the following steps: $\bullet$ TRANSFORM $\rightarrow$ RANK CASES $\rightarrow$ RANK TYPES $\rightarrow$ Ntiles: 5 After the quintiles of the variables of interest are obtained, the second step is to create a cross-tabulation among these variables to relate and investigate the relationships. A $5 * 5$ table is created using the same software via the following steps: -ANALYZE $\rightarrow$ DESCRIPTIVE STATISTICS $\rightarrow$ CROSS-TABS

6. Our calibration of the seven-point Likert dimensions is not based on a fixed number for the crossover point, but follows previous works in taking into account the median score and distribution for each attribute (Russo and Confente, 2019).

7. The more heterogeneity in the survey responses we have, the lower consistency scores we can expect. Overall, consistency is akin to correlation coefficients in regression analysis (Woodside, 2015). We apply several measures of consistency, namely, raw consistency, the "proportional reduction in consistency" measure and symmetric consistency (Ragin (2012) and Schwellnus (2013)). 
$\mathrm{EJM}$

55,13

8. According to Ragin (2009), raw coverage provides information on the degree of overlap of the size of the configuration set and the outcome set, relative to the size of the outcome set, whereas unique coverage partitions raw coverage to identify overlapping explanations.

\section{References}

Ajzen, I. and Fishbein, M. (1980), Understanding Attitudes and Predicting Social Behavior, Prentice-Hall, Englewood Cliffs, N.J.

Aksoy, L. (2013), "How do you measure what you can’t define? The current state of loyalty measurement and management”, Journal of Service Management, Vol. 24 No. 4, pp. 356-381.

Aksoy, L. (2014), "Linking satisfaction to share of deposits: an application of the wallet allocation rule", International Journal of Bank Marketing, Vol. 32 No. 1, pp. $28-42$.

Aksoy, L., Keiningham, T.L., Buoye, A. and Ball, J. (2017), "Linking satisfaction to credit card decisions: an application of the wallet allocation rule", International Journal of Bank Marketing, Vol. 35 No. 2, pp. 205-219.

Alam, I. and Perry, C. (2002), "A customer-oriented new service development process”, Journal of Services Marketing, Vol. 16 No. 6, pp. 515-534.

Almirall, E. and Casadesus-Masanell, R. (2010), "Open versus closed innovation: a model of discovery and divergence", Academy of Management Review, Vol. 35 No. 1, pp. $27-47$.

Anaza, N.A. and Rutherford, B. (2012), "How organizational and employee-customer identification, and customer orientation affect job engagement", Journal of Service Management, Vol. 23 No. 5, pp. 616-639.

Anderson, E. and Mittal, V. (2000), "Strengthening the satisfaction-profit chain", Journal of Service Research, Vol. 3 No. 2, pp. 107-120.

Appiah-Adu, K. and Singh, S. (1998), "Customer orientation and performance: a study of SMEs", Management Decision, Vol. 36 No. 6, pp. 385-394.

Arslanagic-Kalajdzic, M. and Zabkar, V. (2015), "The external effect of marketing accountability in business relationships: exploring the role of customer perceived value", Industrial Marketing Management, Vol. 46, pp. 83-97.

Atuahene-Gima, K. (1995), "An exploratory analysis of the impact of market orientation on new product performance a contingency approach”, Journal of Product Innovation Management, Vol. 12 No. 4, pp. 275-293.

Atuahene-Gima, K. (1996), "Market orientation and innovation”, Journal of Business Research, Vol. 35 No. 2, pp. 93-103.

Bacharach, S.B. (1989), "Organizational theories: some criteria for evaluation", Academy of Management Review, Vol. 14 No. 4, pp. 496-515.

Beckers, S.F., van Doorn, J. and Verhoef, P.C. (2017), "Good, better, engaged? The effect of companyinitiated customer engagement behavior on shareholder value", Journal of the Academy of Marketing Science, pp. 1-18.

Bell, S.J., Auh, S. and Smalley, K. (2005), "Customer relationship dynamics: service quality and customer loyalty in the context of varying levels of customer expertise and switching costs", Journal of the Academy of Marketing Science, Vol. 33 No. 2, pp. 169-183.

Bennett, R., Härtel, C. and McColl-Kennedy, J.R. (2005), "Experience as a moderator of involvement and satisfaction on Brand loyalty in a business-to-business setting 02-314R”, Industrial Marketing Management, Vol. 34 No. 1, pp. 97-107.

Bindroo, V., Mariadoss, B.J., Echambadi, R. and Sarangee, K.R. (2020), "Customer satisfaction with consumption systems", Journal of Business-to-Business Marketing, Vol. 27 No. 1, pp. 1-17. 
Blocker, C.P., Flint, D.J., Myers, M.B. and Slater, S.F. (2011), "Proactive customer orientation and its role for creating customer value in global markets", Journal of the Academy of Marketing Science, Vol. 39 No. 2, pp. 16-233, doi: 10.1007/s11747-010-0202-9.

Blut, M., Evanschitzky, H., Backhaus, C., Rudd, J. and Marck, M. (2016), "Securing business-to-business relationships: the impact of switching costs", Industrial Marketing Management, Vol. 52, pp. 82-90.

Bowen, D.E., Siehl, C. and Schneider, B. (1989), "A framework for analyzing customer service orientations in manufacturing”, Academy of Management Review, Vol. 14 No. 1, pp. 75-95.

Brodie, R.J., Hollebeek, L.D., Juric, B. and Ilic, A. (2011), "Customer engagement: conceptual domain, fundamental propositions, and implications for research", Journal of Service Research, Vol. 14 No. 3, pp. 252-271.

Brodie, R.J., Ilic, A., Juric, B. and Hollebeek, L. (2013), "Consumer engagement in a virtual brand community: an exploratory analysis", Journal of Business Research, Vol. 66 No. 1, pp. 105-114.

Buoye, A. (2016), "An examination of relative satisfaction and share of wallet: investigating the impact of country and customer characteristics", Journal of Service Theory and Practice, Vol. 26 No. 3, pp. 297-314.

Burnham, T.A., Frels, J.K. and Mahajan, V. (2003), "Consumer switching costs: a typology, antecedents, and consequences", Journal of the Academy of Marketing Science, Vol. 31 No. 2, pp. 109-126.

Candi, M., van den Ende, J. and Gemser, G. (2016), "Benefits of customer codevelopment of new products: the moderating effects of utilitarian and hedonic radicalness", Journal of Product Innovation Management, Vol. 33 No. 4, pp. 418-434.

Cannon, J.P. and Homburg, C. (2001), "Buyer - supplier relationships and customer firm costs", Journal of Marketing, Vol. 65 No. 1, pp. $29-43$.

Carlson, J., O'Cass, A. and Ahrholdt, D. (2015), "Assessing customers' perceived value of the online channel of multichannel retailers: a two country examination", Journal of Retailing and Consumer Services, Vol. 27, pp. 90-102.

Casidy, R. and Wymer, W. (2016), "Linking prestige perception with consumption experience, loyalty, and WOM", Marketing Intelligence and Planning, Vol. 34 No. 4, pp. 540-558.

Čater, T. and Čater, B. (2010), "Product and relationship quality influence on customer commitment and loyalty in B2B manufacturing relationships", Industrial Marketing Management, Vol. 39 No. 8, pp. 1321-1333.

Chang, S.J., Van Witteloostuijn, A. and Eden, L. (2010), "From the editors: common method variance in international business research", Journal of International Business Studies, Vol. 41 No. 2, pp. 178-184, doi: 10.1057/jibs.2009.88.

Chebat, J.C., Davidow, M. and Borges, A. (2011), "More on the role of switching costs in service markets: a research note", Journal of Business Research, Vol. 64 No. 8, pp. 823-829.

Chesbrough, H. (2005), "Open innovation: a new paradigm for understanding industrial innovation", Open Innovation: Researching a New Paradigm, Oxford University Press, pp. 1-12.

Chesbrough, H. (2006), Open Innovation: The New Imperative for Creating and Profiting from Technology, Harvard Business Press.

Chesbrough, H. and Brunswicker, S. (2013), Managing Open Innovation in Large Firms, Garwood Center for Corporate Innovation at CA University, Berkeley in US and Fraunhofer Society in Germany, Fraunhofer Verlag, available at: www.ibbnetzwerk-gmbh.com/uploads/media/ Fraunhofer_IAO_-_Open_Innovation.pdf

Colquitt, J.A. and Zapata-Phelan, C.P. (2007), "Trends in theory building and theory testing: a fivedecade study of the academy of management journal", Academy of Management Journal, Vol. 50 No. 6, pp. 1281-1303. 
$\mathrm{EJM}$

55,13

Cooil, B., Keiningham, T., Aksoy, L. and Hsu, M. (2007), "A longitudinal analysis of customer satisfaction and share of wallet: investigating the moderating effect of customer characteristics", Journal of Marketing, Vol. 71 No. 1, pp. 67-83.

Cretu, A.E. and Brodie, R.J. (2007), "The influence of Brand image and company reputation where manufacturers market to small firms: a customer value perspective", Industrial Marketing Management, Vol. 36 No. 2, pp. 230-240.

Dagger, T.S. and David, M.E. (2012), "Uncovering the real effect of switching costs on the satisfactionloyalty association: the critical role of involvement and relationship benefits", European Journal of Marketing, Vol. 46 Nos 3/4, pp. 447-468.

Davis-Sramek, B., Droge, C., Mentzer, J.T. and Myers, M.B. (2009), “Creating commitment and loyalty behavior among retailers: what are the roles of service quality and satisfaction?”, Journal of the Academy of Marketing Science, Vol. 37 No. 4, p. 440.

Day, G. (1969), “A two-dimensional concept of brand loyalty”, Journal of Advertising Research, Vol. 9, pp. 29-35.

Day, G. and Wensley, R. (1988), "Assessing advantage: a framework for diagnosing competitive superiority", Journal of Marketing, Vol. 52 No. 2, pp. 1-20.

Deshpandé, R., Farley, J.U. and Webster, F.E. Jr (1993), "Corporate culture, customer orientation, and innovativeness in Japanese firms: a quadrad analysis", Journal of Marketing, Vol. 57 No. 1, pp. 23-37.

Desouza, K., Awazu, Y., Jha, S., Dombrowski, C., Papagari, S., Baloh, P. and Kim, J.Y. (2008), “Customerdriven innovation", Research-Technology Management, Vol. 51 No. 3, pp. 35-44.

Dick, S. and Basu, K. (1994), "Customer loyalty: toward an integrated conceptual framework", Journal of the Academy of Marketing Science, Vol. 22 No. 2, pp. 99-113.

Dorsch, M.J., Swanson, S.R. and Kelley, S.W. (1998), "The role of relationship quality in the stratification of vendors as perceived by customers", Journal of the Academy of Marketing Science, Vol. 26 No. 2, pp. 128-142.

Dowling, G.R. and Uncles, M. (1997), “Do customer loyalty programs really work?”, Sloan Management Review, pp. 71-82.

Dunphy, S. and Herbig, P. (1995), “Acceptance of innovations: the customer is the key!”, The Journal of High Technology Management Research, Vol. 6 No. 2, pp. 193-209.

Dwyer, F.R., Schurr, P.H. and Oh, S. (1987), "Developing buyer-seller relationships", Journal of Marketing, Vol. 51 No. 2, pp. 11-27.

Eagly, A.H. and Chaiken, S. (1993), The Psychology of Attitudes, Harcourt Brace Jovanovich College Publishers, San Diego.

EC (2018), "Mechanical engineering”, available at: https://ec.europa.eu/growth/sectors/mechanicalengineering_en, (accessed 23 March 2018).

Edvardsson, B., Johnson, M.D., Gustafsson, A. and Strandvik, T. (2000), "The effects of satisfaction and loyalty on profits and growth: products versus services", Total Quality Management, Vol. 11 No. 7, pp. 917-927.

Eggert, A., Kleinaltenkamp, M. and Kashyap, V. (2019), "Mapping value in business markets: an integrative framework", Industrial Marketing Management, Vol. 79, pp. 13-20.

Eggert, A. and Ulaga, W. (2002), "Customer perceived value: a substitute for satisfaction in business markets?", Journal of Business and Industrial Marketing, Vol. 17 Nos 2/3, pp. 107-118.

Eggert, A. and Ulaga, W. (2010), "Managing customer share in key supplier relationships", Industrial Marketing Management, Vol. 39 No. 8, pp. 1346-1355.

Eggert, A., Ulaga, W., Frow, P. and Payne, A. (2018), "Conceptualizing and communicating value in business markets: from value in exchange to value in use", Industrial Marketing Management, Vol. 69, pp. 80-90. 
Ellis, S.C., Henke, J.W. and Kull, T.J. (2012), "The effect of buyer behaviors on preferred customer status and access to supplier technological innovation: an empirical study of supplier perceptions", Industrial Marketing Management, Vol. 41 No. 8, pp. 1259-1269.

Ellis, S.C., Henry, R.M. and Shockley, J. (2010), "Buyer perceptions of supply disruption risk: a behavioral view and empirical assessment", Journal of Operations Management, Vol. 28 No. 1, pp. 34-46.

Enders, C.K. (2010), Applied Missing Data Analysis, Guilford press, New York, NY.

Fishbein, M. and Ajzen, I. (1975), Belief, Attitude, Intention and Behavior: An Introduction to Theory and Research, Addison-Wesley, Reading, Mass.

Flint, D.J., Woodruff, R.B. and Gardial, S.F. (1997), "Customer value change in industrial marketing relationships: a call for new strategies and research", Industrial Marketing Management, Vol. 26 No. 2, pp. 163-175.

Flint, D.J., Blocker, C.P. and Boutin, P.J. (2011), "Customer value anticipation, customer satisfaction and loyalty: an empirical examination", Industrial Marketing Management, Vol. 40 No. 2, pp. 219-230.

Ford, D. (1980), “The development of buyer-seller relationships in industrial markets", European Journal of Marketing, Vol. 14 Nos 5/6, pp. 339-353.

Fornell, C., Johnson, E.W., Anderson, J.C. and Bryant, B.E. (1996), “The American customer satisfaction index: nature, purpose, and findings", Journal of Marketing, Vol. 60 No. 4, pp. 7-18.

Fornell, C., Morgeson, I.I.I., F.V. and Hult, G.T. (2016), "Stock returns on customer satisfaction do beat the market: gauging the effect of a marketing intangible", Journal of Marketing, Vol. 80 No. 5, pp. 92-107.

Foss, N.J. and Lindenberg, S. (2013), "Microfoundations for strategy: a goal-framing perspective on the drivers of value creation", Academy of Management Perspectives, Vol. 27 No. 2, pp. 85-102.

Foss, N.J., Laursen, K. and Pedersen, T. (2011), "Linking customer interaction and innovation: the mediating role of new organizational practices", Organization Science, Vol. 22 No. 4, pp. 980-999.

Frambach, R.T., Fiss, P.C. and Ingenbleek, P.T. (2016), "How important is customer orientation for firm performance? A fuzzy set analysis of orientations, strategies, and environments", Journal of Business Research, Vol. 69 No. 4, pp. 1428-1436.

Friend, S.B., Malshe, A. and Fisher, G.J. (2020), "What drives customer re-engagement? The foundational role of the sales-service interplay in episodic value co-creation", Industrial Marketing Management, Vol. 84, pp. 271-286.

Füller, J. and Matzler, K. (2007), "Virtual product experience and customer participation - a chance for customer-centred, really new products", Technovation, Vol. 27 Nos 6/7, pp. 378-387.

Ganesan, S. (1994), "Determinants of long-term orientation in buyer-seller relationships", Journal of Marketing, Vol. 58 No. 2, pp. 1 -19.

Gardner, T. (2016), "Mechanical engineering in the FY 2016 budget”, available at: www.aaas.org/ fy16budget/mechanical-engineering-fy-2016-budget (accessed 12 July 2016).

Gemser, G. and Perks, H. (2015), "Co-creation with customers: an evolving innovation research field", Journal of Product Innovation Management, Vol. 32 No. 5, pp. 660-665.

Germann, F., Lilien, G.L. and Rangaswamy, A. (2013), "Performance implications of deploying marketing analytics”, International Journal of Research in Marketing, Vol. 30 No. 2, pp. 114-128.

Gligor, D., Bozkurt, S. and Russo, I. (2019), "Achieving customer engagement with social media: a qualitative comparative analysis approach”, Journal of Business Research, Vol. 101, pp. 59-69.

Gounaris, S., Chatzipanagiotou, K., Boukis, A. and Perks, H. (2016), "Unfolding the recipes for conflict resolution during the new service development effort", Journal of Business Research, Vol. 69 No. 10, pp. 4042-4055.

Grant, R.M. (1991), "The resource-based theory of competitive advantage: implications for strategy formulation”, California Management Review, Vol. 33 No. 3, pp. 114-135. 
$\mathrm{EJM}$

55,13

Greckhamer, T., Misangyi, V.F. and Fiss, P.C. (2013), “Chapter 3 the two QCAs: from a small-N to a large-N set theoretic approach", Configurational Theory and Methods in Organizational Research, Vol. 38, pp. 49-75.

Greer, C.R. and Lei, D. (2012), "Collaborative innovation with customers: a review of the literature and suggestions for future research", International Journal of Management Reviews, Vol. 14 No. 1, pp. 63-84.

Gremler, D.D., Van Vaerenbergh, Y., Brüggen, E.C. and Gwinner, K.P. (2020), "Understanding and managing customer relational benefits in services: a meta-analysis", Journal of the Academy of Marketing Science, pp. 1-19.

Grönroos, C. (2011), “A service perspective on business relationships: the value creation, interaction and marketing interface", Industrial Marketing Management, Vol. 40 No. 2, pp. 240-247.

Grönroos, C. and Helle, P. (2010), "Adopting a service logic in manufacturing: conceptual foundation and metrics for mutual value creation", Journal of Service Management, Vol. 21 No. 5, pp. 564-590.

Gruca, T. and Rego, L. (2005), "Customer satisfaction, cash flow and shareholder value”, Journal of Marketing, Vol. 69 No. 3, pp. 115-130.

Guo, L., Xiao, J.J. and Tang, C. (2009), “Understanding the psychological process underlying customer satisfaction and retention in a relational service", Journal of Business Research, Vol. 62 No. 11, pp. 1152-1159.

Gupta, S. and Zeithaml, V. (2006), "Customer metrics and their impact on financial performance", Marketing Science, Vol. 25 No. 6, pp. 718-739.

Guzmán, F., Iglesias, O., Keränen, J., Piirainen, K. and Salminen, R. (2012), "Systematic review on B2B branding: research issues and avenues for future research", Journal of Product and Brand Management, Vol. 21, pp. 6, 404-417.

Hallikainen, H., Savimäki, E. and Laukkanen, T. (2020), "Fostering B2B sales with customer big data analytics", Industrial Marketing Management, Vol. 86, pp. 90-98.

Harmeling, C.M., Moffett, J.W., Arnold, M.J. and Carlson, B.D. (2017), "Toward a theory of customer engagement marketing", Journal of the Academy of Marketing Science, Vol. 45 No. 3, pp. 312-335.

Hartline, M.D., Maxham, I.I.I., J.G. and McKee, D.O. (2000), "Corridors of influence in the dissemination of customer-oriented strategy to customer contact service employees", Journal of Marketing, Vol. 64 No. 2, pp. 35-50.

Helgesen, Ø. (2006), “Are loyal customers profitable? Customer satisfaction, customer (action) loyalty and customer profitability at the individual level", Journal of Marketing Management, Vol. 22 Nos 3/4, pp. 245-266.

Hennig-Thurau, T. and Klee, A. (1997), "The impact of customer satisfaction and relationship quality on customer retention: a critical reassessment and model development", Psychology and Marketing, Vol. 14 No. 8, pp. 737-764.

Herstatt, C. and von Hippel, E. (1992), "Developing new product concepts via the lead user method: a case study in a 'low-tech' field", Journal of Product Innovation Management, Vol. 9 No. 3, pp. 213-221.

Hofmeyr, J., Goodall, V., Bongers, M. and Holtzman, P. (2008), "A new measure of brand attitudinal equity based on the Zipf distribution", International Journal of Market Research, Vol. 50 No. 2, pp. 181-202.

Homburg, C., Koschate, N. and Hoyer, W.D. (2005), "Do satisfied customers really pay more? A study of the relationship between customer satisfaction and willingness to pay", Journal of Marketing, Vol. 69 No. 2, pp. 84-96.

Homburg, C., Stierl, M. and Bornemann, T. (2013), "Corporate social responsibility in business-tobusiness markets: how organizational customers account for supplier corporate social responsibility engagement", Journal of Marketing, Vol. 77 No. 6, pp. 54-72. 
Hooley, G., Broderick, A. and Möller, K. (1998), "Competitive positioning and the resource-based view of the firm”, Journal of Strategic Marketing, Vol. 6 No. 2, pp. 97-116.

Huang, P.L., Lee, B.C. and Chen, C.C. (2017), "The influence of service quality on customer satisfaction and loyalty in B2B technology service industry", Total Quality Management and Business Excellence, pp. 1-17.

Jacoby, J. and Chestnut, R.W. (1978), Brand Loyalty Measurement and Management, Wiley, New York, NY.

Jaworski, B.J. and Kohli, A.K. (1993), "Market orientation: antecedents and consequences", Journal of Marketing, Vol. 57 No. 3, pp. 53-70.

Jean, R.J., Sinkovics, R.R. and Hiebaum, T.P. (2014), "The effects of supplier involvement and knowledge protection on product innovation in customer-supplier relationships: a study of global automotive suppliers in China", Journal of Product Innovation Management, Vol. 31 No. 1, pp. 98-113.

Jolson, M.A. (1997), "Broadening the scope of relationship selling”, Journal of Personal Selling and Sales Management, Vol. 17 No. 4, pp. 75-88.

Kamakura, W.A., Mittal, V., De Rosa, F. and Mazzon, J.A. (2002), “Assessing the service-profit chain”, Marketing Science, Vol. 21 No. 3, pp. 294-317.

Kazadi, K., Lievens, A. and Mahr, D. (2016), "Stakeholder co-creation during the innovation process: identifying capabilities for knowledge creation among multiple stakeholders", Journal of Business Research, Vol. 69 No. 2, pp. 525-540.

Keiningham, T., Aksoy, L. and Cadet, F. (2017), “Operationalizing relative customer value”, Journal of Creating Value, Vol. 3 No. 2, pp. 184-192.

Keiningham, T.L., Aksoy, L., Williams, L. and Buoye, A. (2015c), The Wallet Allocation Rule: Winning the Battle for Share, John Wiley and Sons: New York, NY.

Keiningham, T.L., Perkins-Munn, T., Aksoy, L. and Estrin, D. (2005), "Does customer satisfaction lead to profitability? The mediating role of share-of-wallet", Managing Service Quality: An International Journal, Vol. 15 No. 2, pp. 172-181.

Keiningham, T.L., Cooil, B., Aksoy, L., Andreassen, T.W. and Weiner, J. (2007), "The value of different customer satisfaction and loyalty metrics in predicting customer retention, recommendation, and share-of-wallet", Managing Service Quality: An International Journal, Vol. 17 No. 4, pp. 361-384.

Keiningham, T.L., Cooil, B., Malthouse, E.C., Lariviere, B., Buoye, A., Aksoy, L. and De Keyser, A. (2015b), "Perceptions are relative: an examination of the relationship between relative satisfaction metrics and share of wallet", Journal of Service Management, Vol. 26 No. 1, pp. 2-43.

Keiningham, T.L., Perkins-Munn, T. and Evans, H. (2003), "The impact of customer satisfaction on share-of-wallet in a business-to-business environment", Journal of Service Research, Vol. 6 No. 1, pp. $37-50$.

Kelly, S.W. (1992), "Developing customer orientation among service employees", Journal of the Academy of Marketing Science, Vol. 20, pp. 27-36.

Kennedy, A. (2006), "Electronic customer relationship management (eCRM): opportunities and challenges in a digital world", Irish Marketing Review, Vol. 18 Nos 1/2, pp. 58.

Keränen, J. and Jalkala, A. (2013), "Towards a framework of customer value assessment in B2B markets: an exploratory study", Industrial Marketing Management, Vol. 42 No. 8, pp. 1307-1317.

Kleinaltenkamp, M., Plinke, W. and Söllner, A. (2015), "Theoretical perspectives of business relationships: explanation and configuration”, in Kleinaltenkamp, M., Plinke, W. and Söllner, A. (Eds), Business Relationship Management and Marketing: Mastering Business Markets, Berlin: Springer, pp. 27-54, ISBN 978-3-662-43856-5. 
$\mathrm{EJM}$

55,13

Kostopoulos, K., Papalexandris, A., Papachroni, M. and Ioannou, G. (2011), “Absorptive capacity, innovation, and financial performance", Journal of Business Research, Vol. 64 No. 12, pp. 1335-1343.

Kranzbühler, A.M., Zerres, A., Kleijnen, M.H. and Verlegh, P.W. (2020), "Beyond valence: a metaanalysis of discrete emotions in firm-customer encounters", Journal of the Academy of Marketing Science, pp. 1-21.

Kumar, V. (2016), "Introduction: is customer satisfaction (ir)relevant as a metric?", Journal of Marketing, Vol. 80 No. 5, pp. 108-109.

Kumar, V. and Pansari, A. (2015), "Measuring the benefits of employee engagement", MIT Sloan Management Review, Vol. 56 No. 4, p. 67.

Kumar, V. and Pansari, A. (2016a), "Competitive advantage through engagement", Journal of Marketing Research, Vol. 53 No. 4, pp. 497-514.

Kumar, V. and Rajan, B. (2009), "Profitable customer management: measuring and maximizing customer lifetime value", Management Accounting Quarterly, Vol. 10 No. 3, p. 1.

Kumar, V. and Reinartz, W. (2016b), "Creating enduring customer value”, Journal of Marketing, Vol. 80 No. 6, pp. 36-68.

Kumar, V. and Reinartz, W. (2018), Customer Relationship Management: Concept, Strategy, and Tools, 3rd edition, Springer, Berlin.

Kumar, V., Dalla Pozza, I. and Ganesh, J. (2013), "Revisiting the satisfaction-loyalty relationship: empirical generalizations and directions for future research”, Journal of Retailing, Vol. 89 No. 3, pp. 246-262.

Kwiatek, P., Morgan, Z. and Thanasi-Boçe, M. (2020), "The role of relationship quality and loyalty programs in building customer loyalty", Journal of Business and Industrial Marketing, doi: 10.1108/JBIM-02-2019-0093.

Lam, S.Y., Shankar, V., Erramilli, M.K. and Murthy, B. (2004), "Customer value, satisfaction, loyalty, and switching costs: an illustration from a business-to-business service context", Journal of the Academy of Marketing Science, Vol. 32 No. 3, pp. 293-311.

Lapierre, J. (2000), "Customer-perceived value in industrial contexts", Journal of Business and Industrial Marketing, Vol. 15 Nos 2/3, pp. 122-145.

Lemon, K.N. and Verhoef, P.C. (2016), "Understanding customer experience throughout the customer journey”, Journal of Marketing, Vol. 80 No. 6, pp. 69-96.

Leverin, A. and Liljander, V. (2006), "Does relationship marketing improve customer relationship satisfaction and loyalty?", International Journal of Bank Marketing, Vol. 24 No. 4, pp. 232-251.

Lilien, G.L. (2016), "The B2B knowledge gap”, International Journal of Research in Marketing, Vol. 33 No. 3, pp. 543-556.

Lindgreen, A., Hingley, M.K., Grant, D.B. and Morgan, R.E. (2012), "Value in business and industrial marketing: past, present, and future", Industrial Marketing Management, Vol. 41 No. 1, pp. 207-214.

McColl-Kennedy, J.R., Zaki, M., Lemon, K.N., Urmetzer, F. and Neely, A. (2019), “Gaining customer experience insights that matter", Journal of Service Research, Vol. 22 No. 1, pp. 8-26.

Macdonald, E.K., Kleinaltenkamp, M. and Wilson, H.N. (2016), "How business customers judge solutions: solution quality and value in use”, Journal of Marketing, Vol. 80 No. 3, pp. 96-120.

Maggetti, M. and Levi-Faur, D. (2016), "Dealing with errors in QCA", Political Research Quarterly, pp. 198-204.

Mägi, A.W. (2003), "Share of wallet in retailing: the effects of customer satisfaction, loyalty cards and shopper characteristics", Journal of Retailing, Vol. 79 No. 2, pp. 97-106.

Malhorta, N.K., Kim, S.S. and Patil, A. (2006), "Common method variance in is research: a comparison of alternative approaches and a reanalysis of past research", Management Science, Vol. 52 No. 12, pp. 1865-1883. 
Melnyk, V., Van Osselaer, S.M. and Bijmolt, T.H. (2009), "Are women more loyal customers than men? Gender differences in loyalty to firms and individual service providers", Journal of Marketing, Vol. 73 No. 4, pp. 82-96.

Meunier, G. (2014), "Risk aversion and technology portfolios", Review of Industrial Organization), Vol. 44 No. 4, pp. 1-21.

Meyer-Waarden, L. (2007), “The effects of loyalty programs on customer lifetime duration and share of wallet”, Journal of Retailing, Vol. 83 No. 2, pp. 223-236.

Mitchell, V.W. (1995), "Organizational risk perception and reduction: a literature review", British Journal of Management, Vol. 6 No. 2, pp. 115-133.

Mittal, V. and Kamakura, W.A. (2001), "Satisfaction, repurchase intent, and repurchase behavior: investigating the moderating effect of customer characteristics", Journal of Marketing Research, Vol. 38 No. 1, pp. 131-142.

Mittal, V., Han, K., Lee, J.Y., Im, B. and Sridhar, S. (2018), "Attribute-level satisfaction, overall customer satisfaction, and performance outcomes in business-to-business firms", available at: SSRN: https://ssrn.com/abstract=2964334

Möller, K.K., P. and Törrönen, P. (2003), "Business suppliers' value creation potential: a capabilitybased analysis", Industrial Marketing Management, Vol. 32 No. 2, pp. 109-118.

Nahuis, R., Moors, E.H. and Smits, R.E. (2012), "User producer interaction in context", Technological Forecasting and Social Change, Vol. 79 No. 6, pp. 1121-1134.

Najafi-Tavani, S., Sharifi, H. and Najafi-Tavani, Z. (2016), "Market orientation, marketing capability, and new product performance: the moderating role of absorptive capacity", Journal of Business Research, Vol. 69 No. 11, pp. 5059-5064.

Narver, J.C. and Slater, S.F. (1990), “The effect of a market orientation on business profitability”, Journal of Marketing, Vol. 54 No. 4, pp. 20-35.

Narver, J.C., Slater, S.F. and MacLachlan, D.L. (2004), "Responsive and proactive market orientation and new-product success", Journal of Product Innovation Management, Vol. 21 No. 5, pp. 334-347.

Naumann, E., Williams, P. and Khan, M.S. (2009), "Customer satisfaction and loyalty in B2B services: directions for future research", The Marketing Review, Vol. 9 No. 4, pp. 319-333.

Niraj, R., Gupta, M. and Narasimhan, C. (2001), "Customer profitability in a supply chain”, Journal of Marketing, Vol. 65 No. 3, pp. 1-16.

O'Cass, A. and Ngo, L.V. (2012), “Creating superior customer value for B2B firms through supplier firm capabilities”, Industrial Marketing Management, Vol. 41 No. 1, pp. 125-135.

Oliver, R.L. (1999), “Whence consumer loyalty?”, Journal of Marketing, Vol. 63 No. 4_suppl1, p. 33.

Pansari, A. and Kumar, V. (2017), "Customer engagement: the construct, antecedents, and consequences", Journal of the Academy of Marketing Science, Vol. 45 No. 3, pp. 294-311.

Parasuraman, A., Ball, J., Aksoy, L., Keiningham, T.L. and Zaki, M. (2020), "More than a feeling? Toward a theory of customer delight", Journal of Service Management, doi: 10.1108/JOSM-03-2019-0094.

Payne, A. and Holt, S. (2001), "Diagnosing customer value: integrating the value process and relationship marketing", British Journal of Management, Vol. 12 No. 2, pp. 159-182.

Podsakoff, P.M., MacKenzie, S.B., Lee, J.Y. and Podsakoff, N.P. (2003), "Common method biases in behavioral research: a critical review of the literature and recommended remedies", Journal of Applied Psychology, Vol. 88 No. 5, pp. 879-903.

Prahalad, C.K. and Ramaswamy, V. (2004), "Co-creation experiences: the next practice in value creation", Journal of Interactive Marketing, Vol. 18 No. 3, pp. 5-14.

Pulles, N.J., Schiele, H., Veldman, J. and Hüttinger, L. (2016), "The impact of customer attractiveness and supplier satisfaction on becoming a preferred customer", Industrial Marketing Management, Vol. 54, pp. 129-140. 
$\mathrm{EJM}$

55,13

Ragin, C.C. (2006), "Set relations in social research: evaluating their consistency and coverage", Political Analysis, pp. 291-310.

Ragin, C.C. (2009), "Qualitative comparative analysis using fuzzy sets (fsQCA)”, chp. 5 in Rihoux, B. and Ragin, C.C. (Eds), Applied Social Research Methods: Configurational Comparative Methods: Qualitative Comparative Analysis (QCA) and Related Techniques (Vols. 1-51), SAGE Publications, Inc, Thousand Oaks, CA, doi: 10.4135/9781452226569.

Ragin, C.C. and Davey, S. (2016), Fuzzy-Set/Qualitative Comparative Analysis 3.0, Department of Sociology, University of CA, Irvine, CA.

Ragin, C.C. and Fiss, P.C. (2008), "Net effects analysis versus configurational analysis: an empirical demonstration", Redesigning Social Inquiry: Fuzzy Sets and Beyond, pp. 190-212.

Rauyruen, P. and Miller, K. (2007), "Relationship quality as a predictor of B2B customer loyalty", Journal of Business Research, Vol. 60 No. 1, pp. 21-31.

Rauyruen, P., Miller, K.E. and Groth, M. (2009), "B2B services: linking service loyalty and brand equity”, Journal of Services Marketing, Vol. 23 No. 3, pp. 175-186.

Reichheld, F. (1996), The Loyalty Effect, Harvard Business School Press, Boston.

Reichheld, F.F., Markey, R.G., Jr. and Hopton, C. (2000), "The loyalty effect - the relationship between loyalty and profits", European Business Journal, pp. 134-139.

Reinartz, W. and Eisenbeiss, M. (2015), "Managing customer loyalty to maximize customer equity", in Kumar, V. and Shah, D. (Eds), Handbook of Research in Customer Equity in Marketing, Edgar Elgar, Cheltenham, pp. 139-159.

Reinartz, W. and Kumar, V. (2000), "On the profitability of long-life customers in a noncontractual setting: an empirical investigation and implications for marketing”, Journal of Marketing, Vol. 64 No. 4, pp. 17-35.

Reinartz, W. and Kumar, V. (2002), "The mismanagement of customer loyalty”, Harvard Business Review, Vol. 80 No. 7, pp. 86-94.

Rihoux, B. and Ragin, C.C. (2008), Configurational Comparative Methods: Qualitative Comparative Analysis (QCA) and Related Techniques (Vol. 51), Sage Publications, available at: https://uk. sagepub.com/en-gb/eur/configurational-comparative-methods/book230411

Ritter, T. and Walter, A. (2012), "More is not always better: the impact of relationship functions on customer-perceived relationship value”, Industrial Marketing Management, Vol. 41 No. 1, pp. 136-144.

Ruiz-Martínez, A., Frasquet, M. and Gil-Saura, I. (2019), "How to measure B2B relationship value to increase satisfaction and loyalty", Journal of Business and Industrial Marketing, Vol. 34 No. 8, pp. 1866-1878.

Russo, I. and Confente, I. (2017b), Customer Loyalty and Supply Chain Management: Business-toBusiness Customer Loyalty Analysis, Routledge, New York, NY, ISBN: 978-1-315-16282-9.

Russo, I. and Confente, I. (2019), "From dataset to qualitative comparative analysis (QCA) - challenges and tricky points: a research note on contrarian case analysis and data calibration", Australasian Marketing Journal (AMJ), Vol. 27 No. 2, pp. 129-135.

Russo, I., Confente, I., Gligor, D.M. and Autry, C.W. (2016), “To be or not to be (loyal): is there a recipe for customer loyalty in the B2B context?”, Journal of Business Research, Vol. 69 No. 2, pp. 888-896.

Russo, I., Confente, I., Gligor, D.M. and Cobelli, N. (2017a), "The combined effect of product returns experience and switching costs on B2B customer re-purchase intent", Journal of Business and Industrial Marketing, Vol. 32 No. 5, pp. 664-676.

Salies, E. (2011), "Product innovation when consumers have switching costs", Working paper No. 201107, Observatoire Français des Conjonctures Économiques, Paris.

Sampson, S.E. and Spring, M. (2012), "Customer roles in service supply chains and opportunities for innovation”, Journal of Supply Chain Management, Vol. 48 No. 4, pp. 30-50. 
Santos, J.N., Mota, J. and Baptista, C.S. (2018), "Understanding configurations of value creation functions in business relationships using a fuzzy-set QCA", Journal of Business Research, Vol. 89, pp. 429-434.

Schwellnus, G. (2013), "Eliminating the influence of irrelevant cases on the consistency and coverage of necessary and sufficient conditions in fuzzy-set QCA", The 7th ECPR General Conference, Bordeaux.

Sharma, A. (2007), "The metrics of relationships: measuring satisfaction, loyalty and profitability of relational customers", Journal of Relationship Marketing, Vol. 6 No. 2, pp. 33-50.

Singh, R. and Koshy, A. (2011), "Does salesperson's customer orientation create value in B2B relationships? Empirical evidence from India”, Industrial Marketing Management, Vol. 40 No. 1, pp. 78-85.

Sirdeshmukh, D., Singh, J. and Sabol, B. (2002), "Consumer trust, value, and loyalty in relational exchanges", Journal of Marketing, Vol. 66 No. 1, pp. 15-37.

Skaaning, S.E. (2011), “Assessing the robustness of crisp-set and fuzzy-set QCA results”, Sociological Methods and Research, Vol. 40 No. 2, pp. 391-408.

Smals, R.G. and Smits, A.A. (2012), "Value for value - the dynamics of supplier value in collaborative new product development”, Industrial Marketing Management, Vol. 41 No. 1, pp. 156-165.

Söderlund, M. and Vilgon, M. (1999), "Customer satisfaction and links to customer profitability: an empirical examination of the association between attitudes and behaviour", SSE/EFI Working Paper Series in Business Administration No. 1999: 1, School of Economics, Stockholm.

Sorescu, A. and Sorescu, S.M. (2016), "Customer satisfaction and long-term stock returns", Journal of Marketing, Vol. 80 No. 5, pp. 110-115.

Spivack, A.J. and Woodside, A.G. (2019), "Applying complexity theory for modeling human resource outcomes: antecedent configurations indicating perceived location autonomy and work environment choice", Journal of Business Research, Vol. 102, pp. 109-119.

Srivastava, R.K., Shervani, T.A. and Fahey, L. (1998), "Market-based assets and shareholder value: a framework for analysis", Journal of Marketing, Vol. 62 No. 1, pp. 2-18.

Steiert, R. (2008), "Mechanical engineering: fundamental to most branches of industry", available at: www.industriall-union.org/archive/imf/mechanical-engineering-fundamental-to-most-branchesof-industry (accessed 27 January 2016).

Stępień, B. (2017), "In search of apprehending customers' value perception”, International Journal of Managment and Economics, Vol. 53 No. 1, pp. 99-117.

Storbacka, K., Strandvik, T. and Grönroos, C. (1994), "Managing customer relationships for profit: the dynamics of relationship quality", International Journal of Service Industry Management, Vol. 5 No. 5, pp. 21-38.

Strydom, G., Ewing, M.T. and Heggen, C. (2020), “Time lags, non-linearity and asymmetric effects in an extended service-profit chain”, European Journal of Marketing, Vol. 54 No. 10, doi: 10.1108/EJM12-2019-0906.

Szymanski, D.M. and Henard, D.H. (2001), "Customer satisfaction: a meta-analysis of the empirical evidence", Journal of the Academy of Marketing Science, Vol. 29 No. 1, pp. 16-35.

Tang, Y.E. and Marinova, D. (2020), "When less is more: the downside of customer knowledge sharing in new product development teams", Journal of the Academy of Marketing Science, Vol. 48 No. 2, pp. 288-307.

Terho, H., Eggert, A., Ulaga, W., Haas, A. and Böhm, E. (2017), "Selling value in business markets: individual and organizational factors for turning the idea into action”, Industrial Marketing Management, Vol. 66, pp. 42-55.

Timmer, S. and Kaufmann, L. (2019), "Do managers' dark personality traits help firms in coping with adverse supply chain events?", Journal of Supply Chain Management, Vol. 55 No. 4, pp. 67-97. 
$\mathrm{EJM}$

55,13

Tomczyk, P., Doligalski, T. and Zaborek, P. (2016), "Does customer analysis affect firm performance? Quantitative evidence from the Polish insurance market", Journal of Business Research, Vol. 69 No. 9, pp. 3652-3658.

Ulaga, W. (2003), "Capturing value creation in business relationships: a customer perspective", Industrial Marketing Management, Vol. 32 No. 8, pp. 677-693.

Ulaga, W. and Chacour, S. (2001), "Measuring customer-perceived value in business markets: a prerequisite for marketing strategy development and implementation", Industrial Marketing Management, Vol. 30 No. 6, pp. 525-540.

Ulaga, W. and Eggert, A. (2006), "Value-based differentiation in business relationships: gaining and sustaining key-supplier status", Journal of Marketing, Vol. 70 No. 1, pp. 119-136.

Van Doorn, J. and Verhoef, P.C. (2008), "Critical incidents and the impact of satisfaction on customer share", Journal of Marketing, Vol. 72 No. 4, pp. 123-142.

Verhoef, P.C., Van Doorn, J. and Dorotic, M. (2007), "Customer value management: an overview and research agenda", Marketing Zfp, Vol. 29, pp. 105-122.

Verona, G. (1999), “A resource-based view of product development”, Academy of Management Review, Vol. 24 No. 1, pp. 132-142.

Viio, P. and Grönroos, C. (2016), "How buyer-seller relationship orientation affects adaptation of sales processes to the buying process", Industrial Marketing Management, Vol. 52, pp. 37-46.

Vivek, S., Kazanis, C. and Jain, I. (2019), "Review of engagement drivers for an instrument to measure customer engagement marketing strategy", in Hollebeek, L. and Sprott, D.E. (Eds), Handbook of Research on Customer Engagement, Chapter 12, Edward Elgar Publishing, p. 271.

Von Hippel, E. (1982), "Appropriability of innovation benefit as a predictor of the source of innovation”, Research Policy, Vol. 11 No. 2, pp. 95-115.

Von Hippel, E. (2005), "Democratizing innovation: the evolving phenomenon of user innovation", Journal for Betriebswirtschaft, Vol. 55 No. 1, pp. 63-78.

Von Krogh, G., Ichijo, K. and Nonaka, I. (2000), Enabling Knowledge Creation: How to Unlock the Mystery of Tacit Knowledge and Release the Power of Innovation, Oxford University Press.

Voss, G.B., Godfrey, A. and Seiders, K. (2010), "How complementarity and substitution alter the customer satisfaction-repurchase link", Journal of Marketing, Vol. 74 No. 6, pp. 111-127.

Wagemann, C., Buche, J. and Siewert, M.B. (2016), "QCA and business research: work in progress or a consolidated agenda?”, Journal of Business Research, Vol. 69 No. 7, pp. 2531-2540.

Walsh, G., Evanschitzky, H. and Wunderlich, M. (2008), "Identification and analysis of moderator variables: investigating the customer satisfaction-loyalty link", European Journal of Marketing, Vol. 42 Nos 9/10, pp. 977-1004.

Wang, Y., Lee, J., Fang, E. and Ma, S. (2016b), "Project customization and the supplier revenue-cost dilemmas: the critical roles of supplier-customer coordination", Journal of Marketing, Vol. 81 No. 1, pp. 136-154.

Wang, Q., Zhao, X. and Voss, C. (2016a), "Customer orientation and innovation: a comparative study of manufacturing and service firms", International Journal of Production Economics, Vol. 171, pp. $221-230$.

Watson, G.F., Beck, J.T., Henderson, C.M. and Palmatier, R.W. (2015), "Building, measuring, and profiting from customer loyalty", Journal of the Academy of Marketing Science, Vol. 43 No. 6, pp. 790-825.

Wijekoon, A. and Salunke, S. (2018), "Customer heterogeneity and innovation: a systematic review of the literature", Australian and New Zealand Academy of Management Conference (No. 42516).

Williams, P. and Naumann, E. (2011), "Customer satisfaction and business performance: a firm-level analysis", Journal of Services Marketing, Vol. 25 No. 1, pp. 20-32.

Woodruff, R. (1997), "Customer value: the next source for competitive advantage", Journal of the Academy of Marketing Science, Vol. 25 No. 2, pp. 139-153. 
Woodside, A.G. (2015), "The general theory of behavioral pricing: applying complexity theory to explicate heterogeneity and achieve high-predictive validity", Industrial Marketing Management, Vol. 47, pp. 39-52.

Behavioral outcomes

Wu, L.Y., Chen, K.Y., Chen, P.Y. and Tung, P.J. (2016), "Revisiting associations between specific asset investment and loyal and cooperative behavior: a complexity theory perspective", Journal of Business Research, Vol. 69 No. 9, pp. 3545-3552.

Xia, T. and Roper, S. (2016), "Unpacking open innovation: absorptive capacity, exploratory and exploitative openness, and the growth of entrepreneurial biopharmaceutical firms", Journal of Small Business Management, Vol. 54 No. 3, pp. 931-952.

Zablah, A.R., Bellenger, D.N. and Johnston, W.J. (2004), "An evaluation of divergent perspectives on customer relationship management: towards a common understanding of an emerging phenomenon", Industrial Marketing Management, Vol. 33 No. 6, pp. 475-489.

Zhang, H., Liang, X. and Wang, S. (2016), "Customer value anticipation, product innovativeness, and customer lifetime value: the moderating role of advertising strategy", Journal of Business Research, Vol. 69 No. 9, pp. 3725-3730.

Zietsman, M.L., Mostert, P. and Svensson, G. (2020), "A multidimensional approach to the outcomes of perceived value in business relationships", European Business Review, doi: 10.1108/EBR-102019-0258.

\section{Further reading}

Anderson, E.W., Fornell, C. and Mazvancheryl, S.K. (2004), "Customer satisfaction and shareholder value", Journal of Marketing, Vol. 68 No. 4, pp. 172-185.

Baum, C. (2008), "Stata tip 63: Modeling proportions", The Stata Journal: Promoting Communications on Statistics and Stata, Vol. 8 No. 2, pp. 299-303.

Berthon, P., Mac Hulbert, J. and Pitt, L. (2004), "Innovation or customer orientation? An empirical investigation”, European Journal of Marketing, Vol. 38 No. 9/10, pp. 1065-1090.

Borooah, V.K. (2002), Logit and Probit: Ordered and Multinomial Models, Sage Publications, Thousand Oaks, CA.

Bursac, Z., Gauss, C.H., Williams, D.K. and Hosmer, D.W. (2008), "Purposeful selection of variables in logistic regression", Source Code for Biology and Medicine, Vol. 3 No. 1, p. 1.

Garland, R. (2004), "Share of wallet's role in customer profitability", Journal of Financial Services Marketing, Vol. 8 No. 3, pp. 259-268.

Guadagni, P. and Little, J. (1983), “A logit model of brand choice calibrated on scanner data”, Marketing Science, Vol. 2 No. 3, pp. 203-238.

Homburg, C., Droll, M. and Totzek, D. (2008), "Customer prioritization: does it pay off, and how should it be implemented?", Journal of Marketing, Vol. 72 No. 5, pp. 110-130.

Hosmer, D.W., Lemeshow, S. and Sturdivant, R.X. (2013), Applied Logistic Regression, Vol. 398, John Wiley and Sons, Hoboken, NJ.

Kamakura, W., Mela, C.F., Ansari, A., Bodapati, A., Fader, P., Iyengar, R., Naik, P., Neslin, S., Sun, B., Verhoef, P.C., Wedel, M. and Wilcox, R. (2005), "Choice models and customer relationship management”, Marketing Letters, Vol. 16 Nos 3/4, pp. 279-291.

Keiningham, T.L., Aksoy, L., Komarova, Y.A. and Nejad, M. (2015a), "The chain of effects from customer satisfaction to customer profitability", in Kumar, V. and Shah, D. (Eds), Handbook of Research on Customer Equity in Marketing, Edgar Elgar, Cheltenham, Chp. 11, pp. 265-282.

Larivière, B. (2008), "Linking perceptual and behavioral customer metrics to multiperiod customer profitability", Journal of Service Research, Vol. 11 No. 1, pp. 3-21.

Larivière, B., Keiningham, T.L., Aksoy, L., Yalçin, A., Morgeson, I.I.I., F.V. and Mithas, S. (2016), "Modeling heterogeneity in the satisfaction, loyalty intention, and shareholder value linkage: a 
$\mathrm{EJM}$

55,13

36 cross-industry analysis at the customer and firm levels", Journal of Marketing Research, Vol. 53 No. 1, pp. 91-109.

Long, J.S. and Freese, J. (2006), Regression Models for Categorical Dependent Variables Using Stata, 2nd ed., Stata Press, College Station.

McCue, T., Carruthers, E., Dawe, J., Liu, S., Robar, A. and Johnson, K. (2008), "Evaluation of generalized linear model assumptions using randomization", Unpublished manuscript, available at: www. mun.ca/biology/dschneider/b7932/B7932Final10Dec2008.pdf

McCullagh, P. and Nelder, J.A. (1989), Generalized Linear Models, 2nd ed., Chapman and Hall, London.

Malhotra, N.K., Schaller, T.K. and Patil, A. (2017), "Common method variance in advertising research: when to be concerned and how to control for it", Journal of Advertising, Vol. 46 No. 1, pp. 193-212.

Mittal, V., Anderson, E.W., Sayrak, A. and Tadikamalla, P. (2005), "Dual emphasis and the long-term financial impact of customer satisfaction”, Marketing Science, Vol. 24 No. 4, pp. 544-555.

Mullahy, J. (2011), "Multivariate fractional regression estimation of econometric share models", UCD Geary Institute Discussion Papers, WP2011/33 (November).

Oberhofer, H. and Pfaffermayr, M. (2012), "Fractional response models - a replication exercise of papke and wooldridge (1996)", Contemporary Economics, Vol. 6 No. 3, p. 56.

Qu, R. and Zhang, Z. (2015), "Market orientation and business performance in MNC foreign subsidiaries - moderating effects of integration and responsiveness", Journal of Business Research, Vol. 68 No. 5, pp. 919-924.

Papke, L. and Wooldridge, J. (1996), "Econometric methods for fractional response variables with an application to 401 (k) plan participation rates", Journal of Applied Econometrics, Vol. 11 No. 6, pp. 619-632.

Reichheld, F. and Sasser, W. (1990), "Zero defections: quality comes to services”, Harvard Business Review, Vol. 68 No. 5, pp. 105-111.

Roca-Puig, V. and Escrig-Tena, A.B. (2017), "Examining nonlinear relationships between quality management and financial performance", International Journal of Quality and Reliability Management, Vol. 34 No. 7, pp. 1094-1110.

Rosopa, P.J., Schaffer, M.M. and Schroeder, A.N. (2013), "Managing heteroscedasticity in general linear models", Psychological Methods, Vol. 18 No. 3, pp. 335-351.

Rust, R.T., Moorman, C. and Dickson, P.R. (2002), "Getting returns from service quality: revenue expansion, cost reduction, or both", Journal of Marketing, Vol. 66 No. 4, pp. 7-24.

Tellis, G. (1988), "Advertising loyalty, exposure and brand purchase: a two-stage model of choice", Journal of Marketing Research, Vol. 25 No. 2, pp. 134-145.

Williams, R. (2013), "Marginal effects for continuous variables: Discrete and instantaneous", Change, pp. 1-12. 


\begin{tabular}{|c|c|c|c|c|c|c|c|}
\hline \multirow[b]{3}{*}{ Component } & \multirow[b]{3}{*}{ Total } & \multicolumn{5}{|c|}{ Total variance explained } & \multirow{3}{*}{37} \\
\hline & & \multicolumn{2}{|c|}{ Initial eigenvalues } & \multicolumn{3}{|c|}{ Extraction sums of squared loadings } & \\
\hline & & $\%$ of variance & Cumulative (\%) & Total & $\%$ of variance & Cumulative (\%) & \\
\hline 1 & 6,990 & 43,685 & 43,685 & 6,990 & 43,685 & 43,685 & 0 \\
\hline 2 & 1,230 & 7,689 & 51,375 & & & & \\
\hline 3 & 1,176 & 7,349 & 58,724 & & & & \\
\hline 4 & 0.917 & 5,730 & 64,453 & & & & \\
\hline 5 & 0.764 & 4,773 & 69,227 & & & & \\
\hline 6 & 0.723 & 4,516 & 73,743 & & & & \\
\hline 7 & 0.616 & 3,853 & 77,596 & & & & \\
\hline 8 & 0.554 & 3,464 & 81,059 & & & & \\
\hline 9 & 0.516 & 3,225 & 84,284 & & & & \\
\hline 10 & 0.482 & 3,013 & 87,297 & & & & \\
\hline 11 & 0.420 & 2,623 & 89,920 & & & & \\
\hline 12 & 0.412 & 2,575 & 92,495 & & & & \\
\hline 13 & 0.342 & 2,140 & 94,635 & & & & Table A1. \\
\hline 14 & 0.318 & 1,988 & 96,623 & & & & SPSS Harman sinole- \\
\hline 15 & 0.277 & 1,734 & 98,357 & & & & $\begin{array}{l}\text { SPSS Harman single- } \\
\text { factor test for }\end{array}$ \\
\hline 16 & 0.263 & 1,643 & 100,000 & & & & $\begin{array}{r}\text { factor test for } \\
\text { fractional SOW }\end{array}$ \\
\hline \multicolumn{8}{|r|}{ model } \\
\hline
\end{tabular}

\begin{tabular}{|c|c|c|c|c|c|c|}
\hline \multirow[b]{3}{*}{ Component } & \multicolumn{6}{|c|}{ Total variance explained ${ }^{\mathrm{a}}$} \\
\hline & \multicolumn{3}{|c|}{ Initial eigenvalues } & \multicolumn{3}{|c|}{ Extraction sums of squared loadings } \\
\hline & Total & $\%$ of variance & Cumulative $(\%)$ & Total & $\%$ of variance & Cumulative $(\%)$ \\
\hline 1 & 7,220 & 42,472 & 42,472 & 7,220 & 42,472 & 42,472 \\
\hline 2 & 1,326 & 7,801 & 50,273 & & & \\
\hline 3 & 1,123 & 6,604 & 56,877 & & & \\
\hline 4 & 0.902 & 5,305 & 62,181 & & & \\
\hline 5 & 0.847 & 4,982 & 67,163 & & & \\
\hline 6 & 0.672 & 3,955 & 71,118 & & & \\
\hline 7 & 0.659 & 3,876 & 74,994 & & & \\
\hline 8 & 0.603 & 3,547 & 78,541 & & & \\
\hline 9 & 0.536 & 3,155 & 81,696 & & & \\
\hline 10 & 0.491 & 2,888 & 84,585 & & & \\
\hline 11 & 0.479 & 2,817 & 87,402 & & & \\
\hline 12 & 0.437 & 2,569 & 89,971 & & & \\
\hline 13 & 0.410 & 2,413 & 92,384 & & & \\
\hline 14 & 0.359 & 2,110 & 94,494 & & & \\
\hline 15 & 0.350 & 2,056 & 96,550 & & & \\
\hline 16 & 0.316 & 1,859 & 98,409 & & & \\
\hline 17 & 0.271 & 1,591 & 100,000 & & & \\
\hline
\end{tabular}

Notes: Extraction method: principal component analysis. ${ }^{a}$ Only cases for which include $=1$ are used in the analysis phase
Table A2.

SPSS Harman singlefactor for fractional profitability model 
EJM

55,13

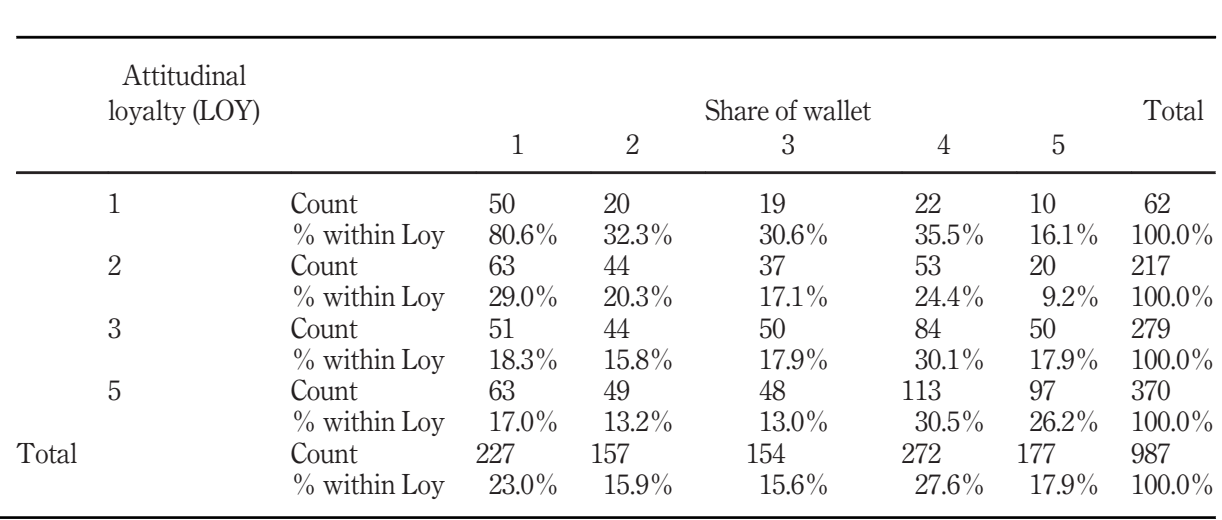

\begin{tabular}{|c|c|c|c|c|c|c|c|c|}
\hline & $\begin{array}{l}\text { Perceived customer } \\
\text { orientation (PCO) }\end{array}$ & & \multicolumn{5}{|c|}{ Share of wallet } & Total \\
\hline & \multirow{2}{*}{1} & Count & 75 & 42 & 45 & 50 & 33 & 245 \\
\hline & & $\%$ within $\mathrm{PCO}$ & $30.6 \%$ & $17.1 \%$ & $18.4 \%$ & $20.4 \%$ & $13.5 \%$ & $100.0 \%$ \\
\hline & \multirow[t]{2}{*}{2} & Count & 64 & 50 & 41 & 65 & 33 & 253 \\
\hline & & $\%$ within $\mathrm{PCO}$ & $25.3 \%$ & $19.8 \%$ & $16.2 \%$ & $25.7 \%$ & $13.0 \%$ & $100.0 \%$ \\
\hline & \multirow[t]{2}{*}{4} & Count & 48 & 37 & 42 & 91 & & \\
\hline & & $\%$ within $\mathrm{PCO}$ & $17.1 \%$ & $13.2 \%$ & $15.0 \%$ & $32.5 \%$ & $22.1 \%$ & $100.0 \%$ \\
\hline & 5 & Count & 40 & 28 & 26 & 66 & 49 & 209 \\
\hline \multirow{2}{*}{ Total } & & Count & 227 & $\begin{array}{l}15.4 / 0 \\
157\end{array}$ & 154 & 272 & 177 & 987 \\
\hline & & $\%$ within $\mathrm{PCO}$ & $23.0 \%$ & $15.9 \%$ & $15.6 \%$ & $27.6 \%$ & $17.9 \%$ & $100.0 \%$ \\
\hline
\end{tabular}

Table A4.

Cross-tabulation of quintiles of cases for share of wallet and perceived customer orientation
Table A3.

Cross-tabulation of quintiles of cases for share of wallet and attitudinal loyalty
Table A5.

Cross-tabulation of quintiles of cases for share of wallet and perceived influence on innovation

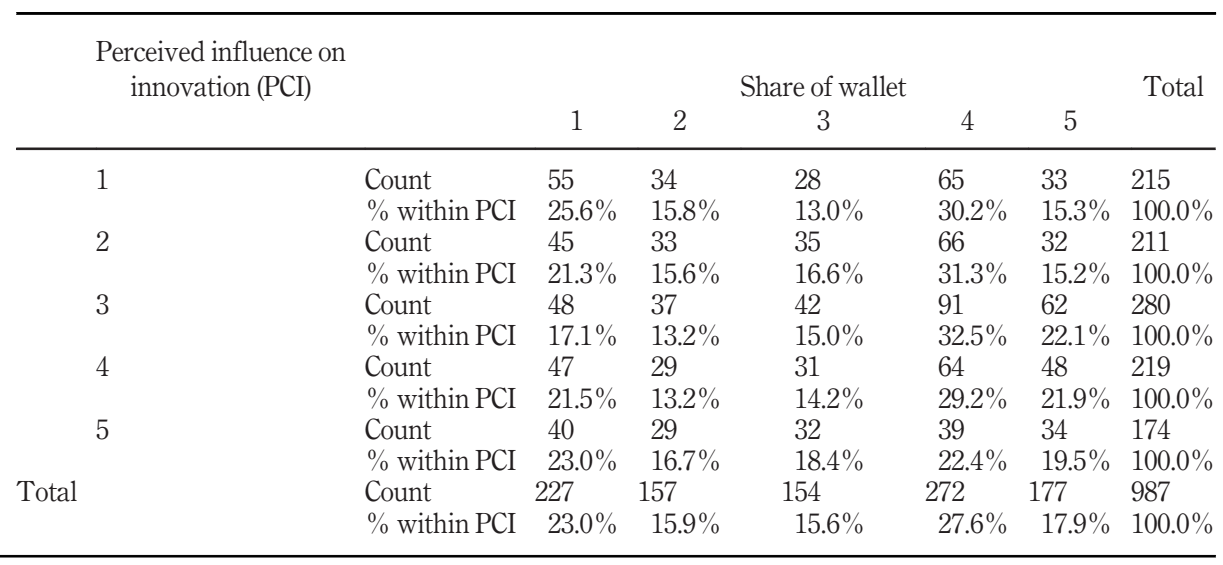


Behavioral

outcomes

\begin{tabular}{|c|c|c|c|c|c|c|c|c|c|}
\hline \multicolumn{2}{|c|}{$\begin{array}{c}\text { Perceived product } \\
\text { innovativeness (PPI) }\end{array}$} & & \multicolumn{5}{|c|}{ Share of wallet } & Total & \multirow[b]{2}{*}{39} \\
\hline & 1 & Count & \multirow{6}{*}{$\begin{array}{l}70 \\
27.8 \% \\
67 \\
21.2 \% \\
52 \\
19.6 \% \\
38 \\
24.7 \%\end{array}$} & \multirow{3}{*}{$\begin{array}{l}46 \\
18.3 \% \\
59 \\
18.7 \%\end{array}$} & \multirow{3}{*}{$\begin{array}{l}37 \\
14.7 \% \\
55 \\
17.4 \%\end{array}$} & \multirow{3}{*}{$\begin{array}{l}66 \\
26.2 \% \\
92 \\
29.1 \%\end{array}$} & \multirow{3}{*}{$\begin{array}{l}33 \\
13.1 \% \\
43 \\
13.6 \%\end{array}$} & \multirow{3}{*}{$\begin{array}{l}252 \\
100.0 \% \\
316 \\
100.0 \%\end{array}$} & \\
\hline & & $\%$ within PPI & & & & & & & \\
\hline & 3 & $\begin{array}{l}\text { Count } \\
\% \text { within PPI }\end{array}$ & & & & & & & \\
\hline & 4 & Count & & 34 & 44 & 76 & & & $\begin{array}{l}\text { 1 able Ab. } \\
\text { Cross-tabulation of }\end{array}$ \\
\hline & 5 & $\begin{array}{l}\text { \% within PPI } \\
\text { Count } \\
\% \text { within PPI }\end{array}$ & & $\begin{array}{l}12.8 \% \\
18 \\
117 \%\end{array}$ & $\begin{array}{l}16.6 \% \\
18 \\
11.7 \%\end{array}$ & $\begin{array}{l}28.7 \% \\
38 \\
24.7 \%\end{array}$ & $\begin{array}{l}22.3 \% \\
42 \\
27.3 \%\end{array}$ & $\begin{array}{l}100.0 \% \\
154 \\
100.0 \%\end{array}$ & $\begin{array}{l}\text { quintiles of cases for } \\
\text { share of wallet and }\end{array}$ \\
\hline Total & & Count & & 157 & 154 & 272 & 177 & 987 & perceived \\
\hline & & $\%$ within PPI & $23.0 \%$ & $15.9 \%$ & $15.6 \%$ & $27.6 \%$ & $17.9 \%$ & $100.0 \%$ & innovativeness \\
\hline
\end{tabular}

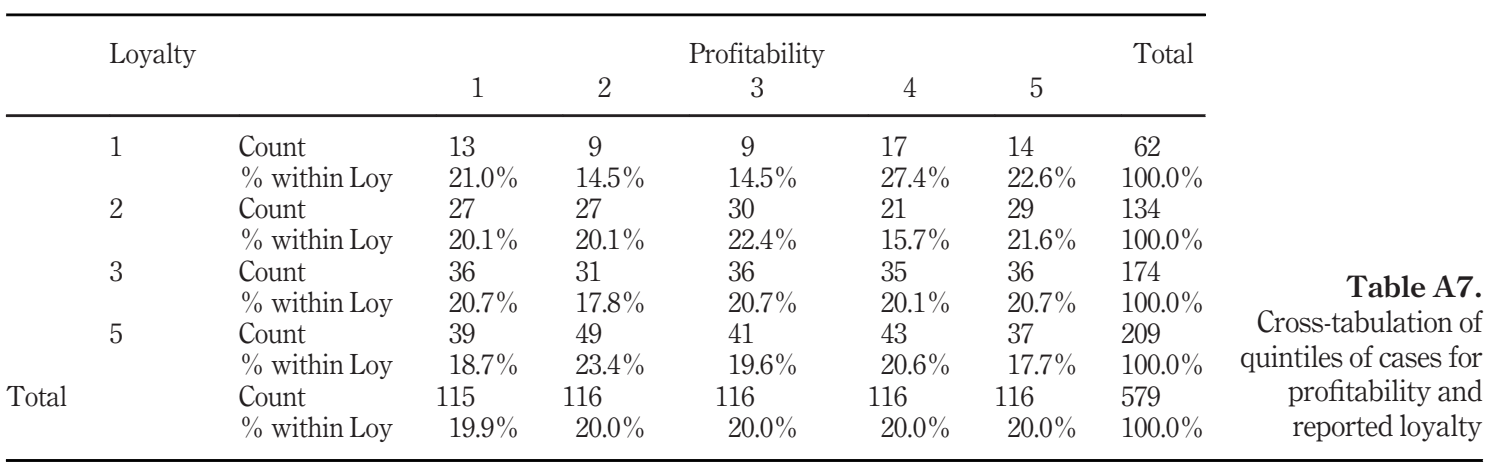

\begin{tabular}{|c|c|c|c|c|c|c|c|c|c|}
\hline & $\begin{array}{l}\text { Perceived product } \\
\text { innovativeness (PPI) }\end{array}$ & & \multicolumn{5}{|c|}{ Profitability } & Total & \\
\hline & \multirow[t]{2}{*}{1} & Count & 23 & 25 & 30 & 35 & 30 & \multirow{2}{*}{$\begin{array}{l}143 \\
100.0 \%\end{array}$} & \\
\hline & & \% within PPI & $16.1 \%$ & $17.5 \%$ & $21.0 \%$ & $24.5 \%$ & $21.0 \%$ & & \\
\hline & \multirow[t]{2}{*}{3} & Count & 47 & 41 & 38 & & & \multirow{2}{*}{$\begin{array}{l}198 \\
100.0 \%\end{array}$} & \\
\hline & & $\%$ within PPI & $23.7 \%$ & $20.7 \%$ & $19.2 \%$ & $16.2 \%$ & $20.2 \%$ & & Table A8. \\
\hline & 4 & $\begin{array}{l}\text { Count } \\
\% \text { within PPI }\end{array}$ & $\begin{array}{l}32 \\
20.1 \%\end{array}$ & $\begin{array}{l}32 \\
20.1 \%\end{array}$ & $\begin{array}{l}30 \\
18.9 \%\end{array}$ & $\begin{array}{l}32 \\
20.1 \%\end{array}$ & $\begin{array}{l}33 \\
20.8 \%\end{array}$ & \multirow{2}{*}{$\begin{array}{l}159 \\
100.0 \% \\
79 \\
100.0 \%\end{array}$} & Cross-tabulation of \\
\hline & 5 & $\begin{array}{l}\text { Count } \\
\% \text { within PPI }\end{array}$ & $\begin{array}{l}13 \\
16.5 \%\end{array}$ & $\begin{array}{l}18 \\
22.8 \%\end{array}$ & $\begin{array}{l}18 \\
22.8 \%\end{array}$ & $\begin{array}{l}17 \\
21.5 \%\end{array}$ & $\begin{array}{l}13 \\
16.5 \%\end{array}$ & & $\begin{array}{l}\text { quintiles of cases for } \\
\text { profitability and }\end{array}$ \\
\hline Total & & Count & 115 & 116 & 116 & 116 & 116 & 579 & perceived \\
\hline & & $\%$ within PPI & $19.9 \%$ & $20.0 \%$ & $20.0 \%$ & $20.0 \%$ & $20.0 \%$ & $100.0 \%$ & innovativeness \\
\hline
\end{tabular}


EJM

55,13

\section{0}

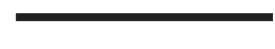

Table A9.

Cross-tabulation of quintiles of cases for profitability and perceived influence on innovation

\begin{tabular}{|c|c|c|c|c|c|c|c|c|}
\hline \multicolumn{2}{|c|}{$\begin{array}{l}\text { Perceived influence on } \\
\text { innovation (PCI) }\end{array}$} & & \multicolumn{5}{|c|}{ Profitability } & Total \\
\hline & 1 & $\begin{array}{l}\text { Count } \\
\text { o within PCI }\end{array}$ & 16 & 26 & 29 & 26 & 28 & 125 \\
\hline & 2 & $\begin{array}{l}\text { Count } \\
\% \text { within PCI }\end{array}$ & $\begin{array}{l}12 \\
231 \%\end{array}$ & $11 \%$ & 8 & $\begin{array}{l}10 \\
192 \%\end{array}$ & $11 \%$ & 52 \\
\hline & 3 & $\begin{array}{l}\text { Count } \\
\% \text { within PCI }\end{array}$ & $\begin{array}{l}46 \\
25.0 \%\end{array}$ & $\begin{array}{l}36 \\
19.6 \%\end{array}$ & $\begin{array}{l}30 \\
16.3 \%\end{array}$ & $\begin{array}{l}39 \\
21.2 \%\end{array}$ & $\begin{array}{l}33 \\
17.9 \%\end{array}$ & $\begin{array}{l}184.0 \% \\
100.0 \%\end{array}$ \\
\hline & 4 & $\begin{array}{l}\text { Count } \\
\% \text { within PCI }\end{array}$ & $\begin{array}{l}19 \\
19.8 \%\end{array}$ & $\begin{array}{l}22 \\
22.9 \%\end{array}$ & $\begin{array}{l}16 \\
16.7 \%\end{array}$ & $\begin{array}{l}21 \\
21.9 \%\end{array}$ & $\begin{array}{l}18 \\
18.8^{\%}\end{array}$ & $\begin{array}{c}96 \\
100.0 \%\end{array}$ \\
\hline & 5 & $\begin{array}{l}\text { Count } \\
\% \text { within PCI }\end{array}$ & $\begin{array}{l}22 \\
18.0 \%\end{array}$ & $\begin{array}{l}21 \\
17.2 \%\end{array}$ & $\begin{array}{l}33 \\
27.0 \%\end{array}$ & $\begin{array}{l}20 \\
16.4 \%\end{array}$ & $\begin{array}{l}26 \\
21.3 \%\end{array}$ & $\begin{array}{l}122 \\
100.0 \%\end{array}$ \\
\hline Total & & $\begin{array}{l}\text { Count } \\
\% \text { within PCI }\end{array}$ & $\begin{array}{l}115 \\
19.9 \%\end{array}$ & $\begin{array}{l}116 \\
20.0 \%\end{array}$ & $\begin{array}{l}116 \\
20.0 \%\end{array}$ & $\begin{array}{l}116 \\
20.0 \%\end{array}$ & $\begin{array}{l}116 \\
20.0 \%\end{array}$ & $\begin{array}{l}579 \\
100.0 \%\end{array}$ \\
\hline
\end{tabular}

Table A10.

Cross-tabulation of quintiles of cases for profitability and perceived customer orientation

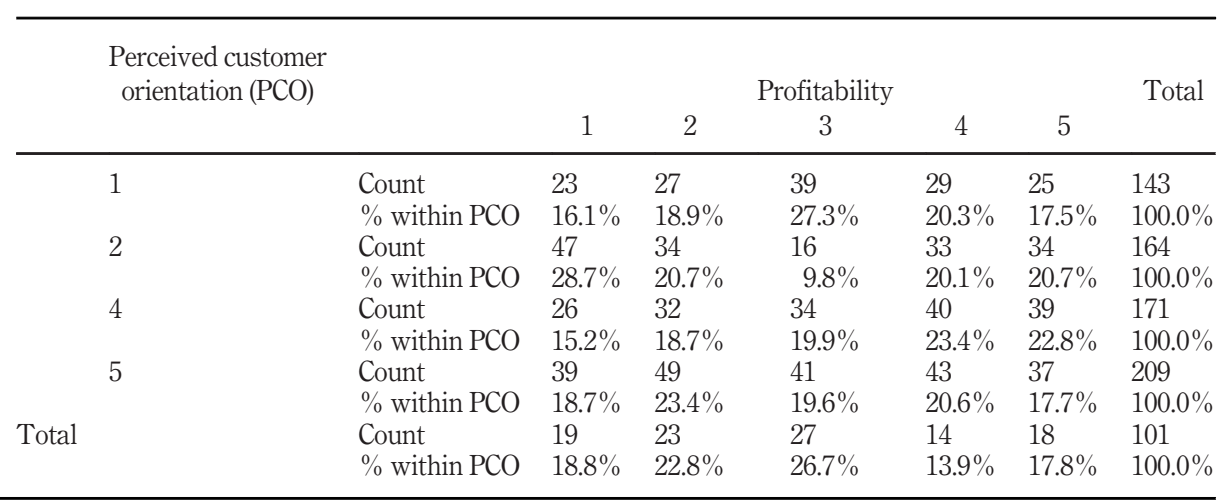

\section{Corresponding author}

Bodo Steiner can be contacted at: bodo.steiner@helsinki.fi

For instructions on how to order reprints of this article, please visit our website: 